\title{
Biomass burning fuel consumption dynamics in the tropics and subtropics assessed from satellite
}

\author{
Niels Andela ${ }^{1,2}$, Guido R. van der Werf ${ }^{1}$, Johannes W. Kaiser ${ }^{3}$, Thijs T. van Leeuwen ${ }^{4,5,6}$, Martin J. Wooster ${ }^{7,8}$, and \\ Caroline E. R. Lehmann ${ }^{9}$ \\ ${ }^{1}$ Faculty of Earth and Life Sciences, VU University, Amsterdam, the Netherlands \\ ${ }^{2}$ Biospheric Sciences Laboratory, NASA Goddard Space Flight Center, Greenbelt, MD 20771, USA \\ ${ }^{3}$ Max-Planck-Institut für Chemie, Mainz, Germany \\ ${ }^{4}$ SRON Netherlands Institute for Space Research, Utrecht, the Netherlands \\ ${ }^{5}$ Institute for Marine and Atmospheric Research Utrecht, Utrecht, the Netherlands \\ ${ }^{6}$ VanderSat B.V., Space Business Park, Huygensstraat 34, 2201 DK, Noordwijk, the Netherlands \\ ${ }^{7}$ King's College London, Environmental Monitoring and Modelling Research Group, Department of Geography, \\ London, WC2R 2LS, UK \\ ${ }^{8}$ NERC National Centre for Earth Observation (NCEO), UK \\ ${ }^{9}$ School of GeoSciences, University of Edinburgh, Edinburgh, EH9 3JN, UK
}

Correspondence to: Niels Andela (niels.andela@nasa.gov)

Received: 13 November 2015 - Published in Biogeosciences Discuss.: 18 January 2016

Revised: 25 May 2016 - Accepted: 1 June 2016 - Published: 28 June 2016

\begin{abstract}
Landscape fires occur on a large scale in (sub)tropical savannas and grasslands, affecting ecosystem dynamics, regional air quality and concentrations of atmospheric trace gasses. Fuel consumption per unit of area burned is an important but poorly constrained parameter in fire emission modelling. We combined satellite-derived burned area with fire radiative power (FRP) data to derive fuel consumption estimates for land cover types with low tree cover in South America, Sub-Saharan Africa, and Australia. We developed a new approach to estimate fuel consumption, based on FRP data from the polar-orbiting Moderate Resolution Imaging Spectroradiometer (MODIS) and the geostationary Spinning Enhanced Visible and Infrared Imager (SEVIRI) in combination with MODIS burned-area estimates. The fuel consumption estimates based on the geostationary and polar-orbiting instruments showed good agreement in terms of spatial patterns. We used field measurements of fuel consumption to constrain our results, but the large variation in fuel consumption in both space and time complicated this comparison and absolute fuel consumption estimates remained more uncertain. Spatial patterns in fuel consumption could be partly explained by vegetation productivity and fire return periods. In South America, most
\end{abstract}

fires occurred in savannas with relatively long fire return periods, resulting in comparatively high fuel consumption as opposed to the more frequently burning savannas in SubSaharan Africa. Strikingly, we found the infrequently burning interior of Australia to have higher fuel consumption than the more productive but frequently burning savannas in northern Australia. Vegetation type also played an important role in explaining the distribution of fuel consumption, by affecting both fuel build-up rates and fire return periods. Hummock grasslands, which were responsible for a large share of Australian biomass burning, showed larger fuel build-up rates than equally productive grasslands in Africa, although this effect might have been partially driven by the presence of grazers in Africa or differences in landscape management. Finally, land management in the form of deforestation and agriculture also considerably affected fuel consumption regionally. We conclude that combining FRP and burned-area estimates, calibrated against field measurements, is a promising approach in deriving quantitative estimates of fuel consumption. Satellite-derived fuel consumption estimates may both challenge our current understanding of spatiotemporal fuel consumption dynamics and serve as reference datasets to improve biogeochemical modelling approaches. Future field 
studies especially designed to validate satellite-based products, or airborne remote sensing, may further improve confidence in the absolute fuel consumption estimates which are quickly becoming the weakest link in fire emission estimates.

\section{Introduction}

Landscape fires play an important role in many ecosystems across the globe, with (sub)tropical savannas of intermediate productivity being most frequently burned (Bowman et al., 2009). Within those (sub)tropical ecosystems, humans are responsible for most of the ignitions and fires have been actively managed for thousands of years (Archibald et al., 2010, 2012; Stott, 2000), partly aided by the vegetation traits of these regions which make them inherently flammable (Archibald et al., 2009). Landscape fires promote open-canopy grassy vegetation over closed canopy woody vegetation (Bond et al., 2005; Lehmann et al., 2011; Scholes and Archer, 1997), providing competitive advantages to grassy rather than woody species in frequently burning landscapes (Sankaran et al., 2008). This fire-driven treegrass competition is further affected by the occurrence of different vegetation traits on the continents (Lehmann et al., 2014; Moncrieff et al., 2014; Staver et al., 2011). Due to the large scale at which biomass burning occurs, inter-annual variability in landscape fires is directly related to (greenhouse) gas concentrations in the atmosphere (Langenfelds et al., 2002) and affects regional air quality (Aouizerats et al., 2015; Crutzen et al., 1979; Langmann et al., 2009; Turquety et al., 2009). Fire regimes and fire management vary widely across (sub)tropical regions (Archibald et al., 2013), while ongoing socio-economic developments are expected to increasingly affect landscape fires and vegetation patterns during the coming century (Andela and van der Werf, 2014; Chen et al., 2013; Grégoire et al., 2013). Fuel consumption per unit area burned $\left(\mathrm{kg} \mathrm{m}^{-2}\right)$, hereafter called fuel consumption for brevity, is a key indicator of the consequences of changing management practices, vegetation characteristics and climate on fire regimes, as well as a key parameter required in fire emission estimates. Yet, spatiotemporal dynamics of fuel consumption on a continental scale remain largely unmeasured and poorly understood (van Leeuwen et al., 2014).

With global annual burned area exceeding the size of India (Giglio et al., 2013) or even the European Union (Randerson et al., 2012), satellite remote sensing is an important source of data to understand the spatiotemporal dynamics of fire. Over the last decade, several new satellite observing systems have become operational, greatly improving our understanding of fire dynamics and fire emission estimates. For example, vegetation productivity (Running et al., 2004) and fire return periods (Archibald et al., 2013) can now be estimated using satellite imagery and data. Broadly speaking, two types of satellite datasets are available to study fire dynamics. These are satellite-derived estimates of burned area that are based on changes in surface reflectance over time (Giglio et al., 2006b, 2013) and active fire observations often accompanied by information on fire radiative power (FRP; Giglio et al., 2006a; Roberts and Wooster, 2008).

Both data types have advantages and disadvantages for the purpose of estimating fire emissions. Burned area remains visible for several days to months after the fire occurred, allowing observations of fires that were obscured by clouds during the satellite overpass, as long as cloud cover is not too persistent (Roy et al., 2008). However, small fires are generally not detected by the burned-area algorithm (Randerson et al., 2012) and fuel consumption has to be modelled if burned area is used to calculate emissions (van der Werf et al., 2010). Active fire observations, on the other hand, often include FRP associated with the detected fire, which can be used to estimate fire radiative energy (FRE), which is directly related to dry matter burned (Wooster et al., 2005). When FRP data of geostationary instruments are used, the full fire diurnal cycle is observed and FRE and dry matter burned can be estimated by integrating the FRP observations over time (Roberts et al., 2005). However, geostationary satellites are located relatively far from the Earth and therefore have a relatively coarse pixel size. Consequently, fires with low FRP fall below their detection threshold (Freeborn et al., 2009). Polarorbiting instruments, like the Moderate Resolution Imaging Spectroradiometer (MODIS), are located closer to the Earth and therefore have a higher spatial resolution and sensitivity to fires with low FRP. However, with approximately four daily observations under ideal conditions, the MODIS instruments provide relatively poor sampling of the fire diurnal cycle (Ellicott et al., 2009; Freeborn et al., 2011; Vermote et al., 2009). On top of the orbit-specific limitations, active fire observations from both polar-orbiting and geostationary instruments are sensitive to cloud cover, and radiation of surface fires may be partly obscured by tree cover (Freeborn et al., 2014a).

To date, most knowledge on fuel consumption dynamics stems from a limited number of field campaigns (summarized in van Leeuwen et al., 2014). These studies provide great detail and have considerably advanced our understanding of fuel consumption dynamics, but upscaling is problematic because fuel consumption is highly variable in space and time (Boschetti and Roy, 2009; Hély et al., 2003a; Hoffa et al., 1999). As an alternative approach, Roberts et al. (2011) combined burned-area data from MODIS with FRE estimated from the geostationary Meteosat Spinning Enhanced Visible and Infrared Imager (SEVIRI) instrument, creating the first fully satellite-derived fuel consumption map for Africa. Although at that time only 1 year of SEVIRI data was available, Roberts et al. (2011) found some striking differences between their estimates of fuel consumption and the ones resulting from the biogeochemical modelling framework used in the Global Fire Emission Database version 3 (GFED3; van 
der Werf et al., 2010). The satellite-derived fuel consumption estimates of Roberts et al. (2011) were considerably lower than the ones from GFED in savanna regions, which may partly be explained by the low sensitivity of the SEVIRI instrument to small fires and an overestimate by GFED3. However, spatial patterns were also different, indicating that such methods can provide new insights into the distribution of fuel consumption and of fuel build-up processes.

The objective of this study is to gain further insights into the spatial distribution and drivers of fuel consumption. Initially, fuel consumption is estimated across Sub-Saharan Africa by building upon the previous work of Roberts et al. $(2009,2011)$ that combined active fire FRP data from the geostationary SEVIRI instrument with burned-area data from MODIS. We used a similar approach, but with longer time series (2010-2014), in an attempt to provide more statistically representative fuel consumption estimates, particularly in less frequently burning grid cells. Then we used a similar method but now based on MODIS FRP data to expand our study region to include South America and Australia, in addition to Sub-Saharan Africa. In situ fuel consumption observations were used to calibrate the MODIS-derived fuel consumption estimates to match field-measured values. Because FRP observations may be partly obscured by tree cover (Freeborn et al., 2014a), we limited our study to low tree cover land cover classes. Results were compared to the SEVIRI-derived fuel consumption estimates and the estimate derived using the biochemical GFED modelling framework. Finally, we used the spatial distribution of our fuel consumption estimates to explore the drivers of fuel consumption in the study regions.

\section{Data}

In this study we combined burned-area data (Sect. 2.1) with FRP data to derive fuel consumption estimates. We commenced by following the approach of Roberts et al. (2011), based on FRP data provided by the geostationary SEVIRI instrument (Sect. 2.2), and then developed a new method using the FRP data from the polar-orbiting MODIS instruments (Sect. 2.3). Information on land cover type, fire return periods and net primary productivity (NPP) was used to better understand the spatial variation in fuel consumption, while results were also compared to fuel consumption estimates extracted from the GFED4s dataset (Sect. 2.4). Both methods to derive fuel consumption were based on the native resolution of the FRP data, but end results were rescaled to $0.25^{\circ}$ resolution for comparison to drivers and in the case of the MODIS FRP detections to include a representative sample size.

\subsection{MODIS burned area}

The MCD64A1 burned-area dataset, based on land surface spectral reflectance observations made by the MODIS instru- ments aboard the Terra and Aqua satellites, provides daily $500 \mathrm{~m}$ resolution global burned-area estimates from August 2000 onwards (Giglio et al., 2009, 2013). Partly because of the relatively high spatial resolution of the MODIS instruments, MODIS-based burned-area data were found to perform best out of several burned-area products (Padilla et al., 2014; Roy and Boschetti, 2009). Despite this relatively good performance, the burned-area product still often misses the smallest fires, which according to Randerson et al. (2012) may comprise a large fraction (over one-third) of the overall global burned area.

We estimated the mean fire return period based on the 14 years of MCD64A1 burned-area data by recording how many times each $500 \mathrm{~m}$ resolution MODIS grid cell had burned during the 2001-2014 period. The fire return period is estimated as 14 divided by the number of times that a given grid cell burned during the 14-year study period. This method yields best results for frequently burning grid cells, where the accuracy is thought to be high. For grid cells burning only once during the 14 years it is likely that in many cases the actual fire return period may in fact be longer, leading to an underestimation of fire return periods. For grid cells without any burned-area observations no fire return period could be calculated. We then calculated the mean fire return period for each $0.25^{\circ}$ grid cell as the mean return period of all $500 \mathrm{~m}$ grid cells within each $0.25^{\circ}$ grid cell, weighted by burned area. When estimating the mean fire return period per $0.25^{\circ}$ grid cell, a $500 \mathrm{~m}$ grid cell with a fire return period of 1 year (burning 14 times during the study period) was thus assigned a weight 14 times larger than a $500 \mathrm{~m}$ grid cell that burned only once during the study period (having a fire return period of 14 years). We decided to weight the fire return period by burned area to facilitate the interpretation of the mean fuel consumption conditions, which will in a similar way be dominated by the most frequently burning grid cells.

\subsection{SEVIRI FRP data}

The SEVIRI instrument, aboard the geostationary Meteosat Second Generation satellites, is located at $0^{\circ}$ longitude and latitude and provides active fire observations at $3 \mathrm{~km}$ spatial resolution at nadir, degrading with increasing view angle (Freeborn et al., 2011; Roberts and Wooster, 2008). The sensitivity of the instrument to fires with low FRP is lower than the sensitivity of the MODIS instruments due to the coarser pixel size, but the instrument provides $15 \mathrm{~min}$ interval observations capturing almost the full fire diurnal cycle, cloud cover permitting. Here we used the Meteosat SEVIRI FRP-PIXEL product providing FRP data at $15 \mathrm{~min}$ interval on the original SEVIRI spatial resolution (Roberts and Wooster, 2008; Wooster et al., 2015). The FRP-PIXEL product is freely available and can be downloaded from the Land Surface Analysis Satellite Applications Facility (http://landsaf.meteo.pt), from the EUMETSAT EO Portal (https://eoportal.eumetsat.int/) or via the EUMETCast dis- 
semination service (http://www.eumetsat.int), both in realtime and archived form.

\subsection{MODIS FRP data}

The MODIS instruments aboard the polar-orbiting Terra (MOD) and Aqua (MYD) satellites provide global FRP data at $1 \mathrm{~km}$ resolution (Giglio et al., 2006a). To calculate fuel consumption we used the MOD14 and MYD14 version 005 active fire data for the full period that both satellites were in orbit (2003-2014). The $1 \mathrm{~km}$ resolution translates into a higher sensitivity to small fires (i.e. low FRP), although the FRP sensitivity of MODIS decreases towards the swath edges (Freeborn et al., 2011). Because of the importance of a large sample size for our analysis, we included the MODIS FRP data from all active fire detections (low to high confidence active fire pixels).

The number of daily overpasses of the MODIS instruments is lowest in the tropics and increases towards the poles due to orbital convergence. Cloud cover permitting, the two MODIS instruments provide around four daily observations in the (sub)tropics. We combined information from the MOD03 and MYD03 geolocation datasets associated with each MODIS overpass with the MOD14 and MYD14 cloud cover data in order to derive the mean daily MODIS detection opportunity (i.e. cloud-free overpasses) during the burning season in a similar way to the processing used in the Global Fire Assimilation System (GFAS; Kaiser et al., 2012). Because of the large size of the MOD03 and MYD03 data, we based this part of the analysis on 4 years of data (2009-2012), enough to calculate a representative mean value. MODIS data are freely available and can be downloaded from NASA at http://reverb.echo.nasa.gov.

\subsection{Other datasets}

We derived information on land cover type from the MODIS MCD12C1 version 051 product, using the University of Maryland land cover classification (Friedl et al., 2002). In this study we focussed on low tree cover vegetation types including savannas, woody savannas, grasslands, shrublands and croplands. Forests and bare or sparsely vegetated areas were excluded. Because the land cover fraction having closed shrublands was small and contained very little of the overall fire activity, we merged open and closed shrublands into one "shrubland" class. The dominant land cover type was based on 2003-2012 data, because post-2012 data were not available to us at the time of the study.

Net Primary Production (NPP) was derived from the Terra MODIS MOD17A3 version $0551 \mathrm{~km}$ annual product (Running et al., 2004), and we used the mean NPP over 20032010 (post-2010 data were not available). Units of NPP were in $\mathrm{g} \mathrm{C} \mathrm{m}^{-2} \mathrm{yr}^{-1}$, and for comparison to estimates of fuel consumption in units of dry matter (DM) burned per square me- tre we assumed a vegetation (fuel) carbon content of $45 \%$ (Andreae and Merlet, 2001; Barbosa and Fearnside, 2005).

Fuel consumption estimates from field studies were used to calibrate and evaluate the fuel consumption estimates from satellite. Peer reviewed studies were compiled into a field observation database for several biomes by van Leeuwen et al. (2014), and here we used their values for the savanna biome, including grasslands and (woody) savannas.

Finally, we compared our results to modelled fuel consumption estimates over the same period (2003-2014) extracted from the GFED4s dataset $\left(0.25^{\circ}\right.$ spatial resolution). Methods used in GFED4s are based on GFED3.1 (van der Werf et al., 2010) but with two main improvements. The first one is the inclusion of small fire burned area in addition to the burned area observed by the MCD64A1 product (Randerson et al., 2012) and the second one is further tuning of the model to better match fuel consumption estimates from the database of van Leeuwen et al. (2014). This involved mostly faster turnover rates of leaf and litter in the model to lower fuel consumption rates in low tree cover regions. GFED data can be downloaded from http://globalfiredata.org/.

\section{Methods}

The primary objective of this study was to provide further insights into the spatial distribution of vegetation fire fuel consumption in key (sub)tropical biomass burning regions, and also to provide insights into its most important drivers. We first derived a fuel consumption map for Sub-Saharan Africa using SEVIRI FRP data and the MCD64A1 burnedarea product, using an approach similar to that of Roberts et al. (2011). We derived FRE per unit area burned by combining the SEVIRI FRP data and burned-area data, which were subsequently converted into an estimate of fuel consumption (in $\mathrm{kg}$ DM burned per $\mathrm{m}^{-2}$ burned) using the conversion factor of Wooster et al. (2005); see Sect. 3.1. To expand our understanding of fuel consumption beyond Africa, we explored whether a similar approach could be applied to MODIS FRP data. This approach was similar to the methods of Kaiser et al. (2012) but with a few adjustments to calculate fuel consumption. Because of the uncertainties in the absolute FRE estimates, we correct the FRE estimates by calibration against in situ field observations to estimate fuel consumption (Sect. 3.2). We present results of this processing for three (sub)tropical biomass burning regions: South America, Sub-Saharan Africa and Australia. In those regions we explored the potential drivers of the spatial distribution of fuel consumption. Fuel consumption also varies in time, as a function of fuel loads and combustion completeness. These temporal effects are not specifically investigated here but are explored in the discussion. Finally, the results were compared to model-derived fuel consumption estimates of GFED4s. 


\subsection{Converting SEVIRI FRP to fuel consumption using laboratory measurements}

Roberts et al. (2011) combined estimates of dry matter burned $(\mathrm{kg})$, based on 1 year of FRP data from the geostationary Meteosat SEVIRI instrument, with MODIS-derived burned area mapping $\left(\mathrm{m}^{2}\right)$ to derive fuel consumption estimates $\left(\mathrm{kg} \mathrm{m}^{-2}\right)$ for Africa. Here we followed a similar approach, but now including 5 years of SEVIRI data (20102014), to get a better understanding of fuel consumption in infrequently burning zones and to derive more representative mean fuel consumption estimates in general. An overview of this method is given in the flow chart of Fig. 1a and explained in more detail below.

First, the daily burned-area data $(500 \mathrm{~m}$ resolution) were reprojected to the native SEVIRI imaging grid ( $3 \mathrm{~km}$ resolution at nadir). Because of the uncertainty in the burn date in the burned-area product (Boschetti et al., 2010; Giglio et al., 2013), and the fact that a fire can burn for multiple days, we followed Roberts et al. (2011) and assumed that all FRP detections within one week of the burned area observations (before or after; i.e. in total 15 days) in a given grid cell belonged to the same fire. Roberts et al. (2011) investigated the distribution of active fire detections in the days around the "day of burn" as determined by the burned-area dataset and showed that $>80 \%$ of the SEVIRI active fire detections occurred within 2 days before or after the day of burn, after which the sensitivity rapidly decreases. Use of a 15-day time window thus includes nearly all FRE that can be associated with a given fire, while the possible effect of small fires with observed FRP but without corresponding burned area (burning within the same pixel and time window) on the fuel consumption estimates is likely small. Grid cells having only burned-area observations but no corresponding FRP detections are likely related to fires having relatively low FRP or those that were obscured by clouds (Roberts et al., 2011). These areas (3\% of annual burned area) were excluded from our analysis. Moreover, about half $(54 \%)$ of the burned-area detections showed over $20 \%$ cloud cover and/or missing data during the 15-day accumulation period, possibly reducing FRE estimates. We decided not to exclude these data so as to maintain as large a sample as possible, but we investigated the impact of this effect via a comparison of results including and excluding partial cloud cover and missing data.

As a second step, the $15 \mathrm{~min}$ interval SEVIRI FRP detections were integrated over time to calculate FRE. This FRE was then converted into dry matter burned using the conversion factor $\left(0.368 \mathrm{~kg} \mathrm{MJ}^{-1}\right)$ based on lab experiments of various fuel types by Wooster et al. (2005). We limited the study to the spatial distribution of mean fuel consumption and calculated fuel consumption (FC) for each $0.25^{\circ}$ grid cell $(x, y)$ based on

$\operatorname{FC}(\text { SEVIRI })_{x, y}=\frac{\sum_{2010}^{2014} \mathrm{DM}_{-} \text {burned }_{x, y}}{\sum_{2010}^{2014} \mathrm{BA}_{x, y}}$, where $\sum_{2010}^{2014} \mathrm{DM} \_$burned corresponds to the sum of dry matter burned of each SEVIRI grid cell within the coarser $0.25^{\circ}$ grid over the study period with a corresponding burned-area observation, and $\sum_{2010}^{2014} \mathrm{BA}$ is the sum of burned area (BA) for each $0.25^{\circ}$ grid cell with corresponding FRE over the study period.

\subsection{Converting MODIS FRP to fuel consumption using in situ measurements}

With approximately four daily overpasses, MODIS provides only a sample of daily fire activity and FRP. Various approaches have been developed to derive FRE (J) and dry matter burned $(\mathrm{kg})$ estimates from the MODIS FRP data (e.g. Ellicott et al., 2009; Freeborn et al., 2009, 2011; Kaiser et al., 2012; Vermote et al., 2009). However, methods to convert MODIS FRP to FRE usually work at the relatively coarse spatial and/or temporal scale (e.g. $0.5^{\circ}$ monthly) required to accumulate a statistically valid number of FRP observations. The sensitivity of the MODIS burned-area product to "small fires" is considerably worse than that of the MODIS active fire product (Randerson et al., 2012), and within each relatively large grid cell the proportion of FRP observations that originate from these small (unmapped) burned areas remains unknown. Therefore, these methods cannot directly be used to estimate fuel consumption. The method developed here to derive FRE is similar to the one used within the GFAS version 1 (Heil et al., 2010; Kaiser et al., 2012), but observations of "small fires" (having FRP detections but no corresponding burned area) were discarded (by working at the native MODIS $1 \mathrm{~km}$ resolution). Because the objective here was to estimate fuel consumption per unit area burned instead of total dry matter burned, the impact of ignoring the smallest fires is small, as long as fuel consumption in such fires is of a similar magnitude or their relative fraction is low. An overview of the method is shown in the flow chart of Fig. 1b, and explained in more detail below.

As with the approach detailed in Sect. 3.1, the daily MODIS burned-area data $(500 \mathrm{~m}$ resolution) was rescaled to the resolution of the active fire product (for MODIS a $1 \mathrm{~km}$ resolution). Also, all MODIS FRP detections within a week before or a week after a $1 \mathrm{~km}$ grid cell was flagged as "burned" were assumed to be part of the same fire. FRP detections without corresponding burned area within this period were assumed to correspond to small fires and were excluded from the analysis. In contrast to the approach based on SEVIRI data, here all burned area observations were included. The FRP detections made by the MODIS instruments are more sensitive to small fires than the burned-area product (Randerson et al., 2012), and it can therefore be reasonably assumed that the vast majority of fires that leave a detectable burned-area signal will be observed by the MODIS instruments if there is a MODIS detection opportunity (i.e. a noncloud-obstructed overpass of one of the MODIS instruments) during the fire. 
The FRP recorded by the polar-orbiting MODIS instruments are affected by the MODIS scan geometry (Freeborn et al., 2011), cloud cover, tree cover (Freeborn et al., 2014b), and the fire diurnal cycle and daily number and timing of overpasses (Andela et al., 2015). Hence, whilst a single MODIS FRP detection is somewhat representative of the overall fire activity in a certain grid cell, its value is also influenced by these other factors (e.g. Andela et al., 2015; Boschetti and Roy, 2009; Freeborn et al., 2009). Moreover, temporal variations in fuel consumption may be considerable, driven by climate, vegetation type, management, and fire return periods (Hély et al., 2003a; Savadogo et al., 2007; Shea et al., 1996). Minimizing the impact of these types of perturbations is in part why methods developed to estimate FRE from MODIS FRP generally require the accumulation of MODIS FRP observations over relatively coarse spatiotemporal scales (e.g. Freeborn et al., 2009; Vermote et al., 2009). We further investigated the combined effect of all these factors on the FRP data by studying the distribution of FRP observations for a frequently burning grid cell in Africa.

Following the methods applied within GFAS (Heil et al., 2010; Kaiser et al., 2012), FRE was estimated by assuming that the observed daily fire activity (i.e. FRP) at cloud-free MODIS overpasses is representative of daily fire activity. To create a sufficiently large and "representative" sample size, burned-area detections and FRP detections with corresponding burned area were aggregated to a $0.25^{\circ}$ spatial resolution for the full period that both Aqua and Terra were in orbit (2003-2014). Subsequently the total emitted FRE (J) over the study period was calculated per grid cell as the sum of FRP ( $\mathrm{W}$ or $\mathrm{J} \mathrm{s}^{-1}$ ) multiplied by the mean duration between two MODIS detection opportunities (s) during the burning season (calculated using the mean number of cloud-free overpasses per day weighted by monthly burned area). This way we implicitly correct for variation in the daily detection opportunity caused by cloud cover and/or the MODIS orbits (e.g. Andela et al., 2015; Kaiser et al., 2012). For further analysis we only include those $0.25^{\circ}$ grid cells containing at least 50 MODIS FRP detections (together responsible for $96 \%$ of annual burned area).

Similar to the method based on the SEVIRI data we used the $0.368 \mathrm{~kg} \mathrm{MJ}^{-1}$ conversion factor to derive fuel consumption (Wooster et al., 2005). However, because of the uncertainties in the FRE estimates, we calibrated our results against field measurements. We used simple linear regression forced through the origin between the uncorrected MODISderived fuel consumption $\left(\mathrm{kg} \mathrm{m}^{-2}\right)$ and the corresponding field measurements of fuel consumption compiled by van Leeuwen et al. (2014) to derive a correction factor between the MODIS-derived FRE per unit area burned $\left(\mathrm{MJ} \mathrm{m}^{-2}\right)$ and the emitted FRE at the Earth's surface. Bootstrapping ( $n=10000$, bias-corrected and accelerated bootstrap) was used to study the uncertainty associated with this correction factor. From the field measurement database we included all measurements conducted in grasslands, savannas and woody

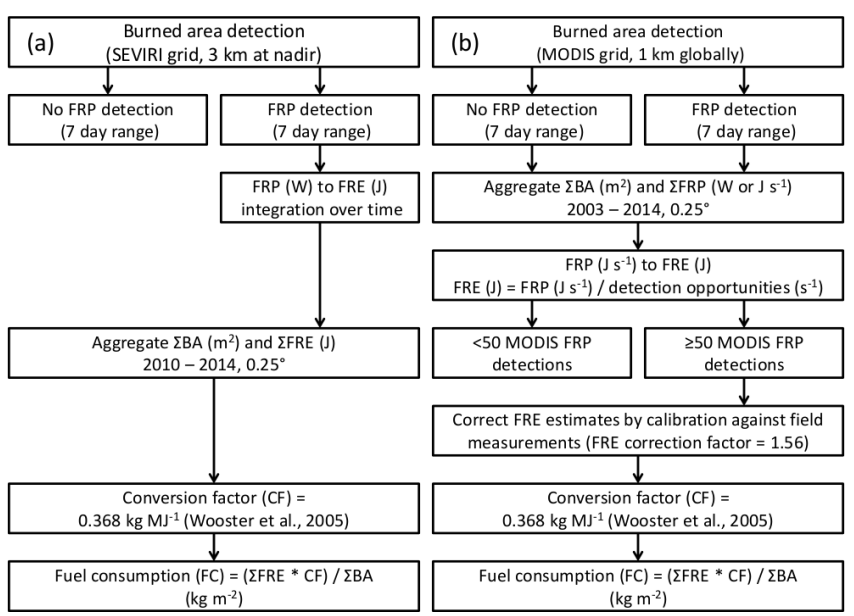

Figure 1. Methods to derive $0.25^{\circ}$ fuel consumption estimates based on two different approaches. (a) The pathway used to combine FRP data of the geostationary SEVIRI instrument with burnedarea data to derive fuel consumption (Roberts et al., 2011; Sect. 3.1). (b) The pathway used to derive fuel consumption by combining FRP data of the polar-orbiting MODIS instruments with burnedarea data (Sect. 3.2). Note that FRP detections without corresponding burned area, associated with small fires, are excluded in both processing chains.

savannas (Table 1). The results were also compared to the results based on the approach using the SEVIRI instrument outlined in Sect. 3.1. However, in that case we did not apply the FRE correction factor so as to better understand the impact of the different sensor characteristics and methods used here on the fuel consumption estimates.

\section{Results}

\subsection{Comparing SEVIRI- and MODIS-derived fuel consumption}

To provide new insights into the specific qualities and limitations of polar-orbiting and geostationary-based FRP data, we compared the mean fuel consumption $\left(\mathrm{kg} \mathrm{m}^{-2}\right)$ estimates based on our approach using SEVIRI FRP data (Fig. 2a) with our approach using MODIS FRP data (Fig. 2c). Although later on the MODIS-based FRE estimates are calibrated against field measurements, here we use the uncorrected FRE estimates to provide insights into the effect of sensor characteristics and our methods on absolute FRE estimates. We used linear regression fitted through the origin (Fig. 2b) in order to compare the results. Total estimated FRE, and thus fuel consumption, based on the MODIS instruments was roughly two times larger than SEVIRI-derived fuel consumption. On top of these absolute differences, the spatial patterns were not uniform (Fig. $2 b$ and d), for which we identified two main causes: first, the MODIS-based fuel consumption was consistently higher in south-eastern Africa 

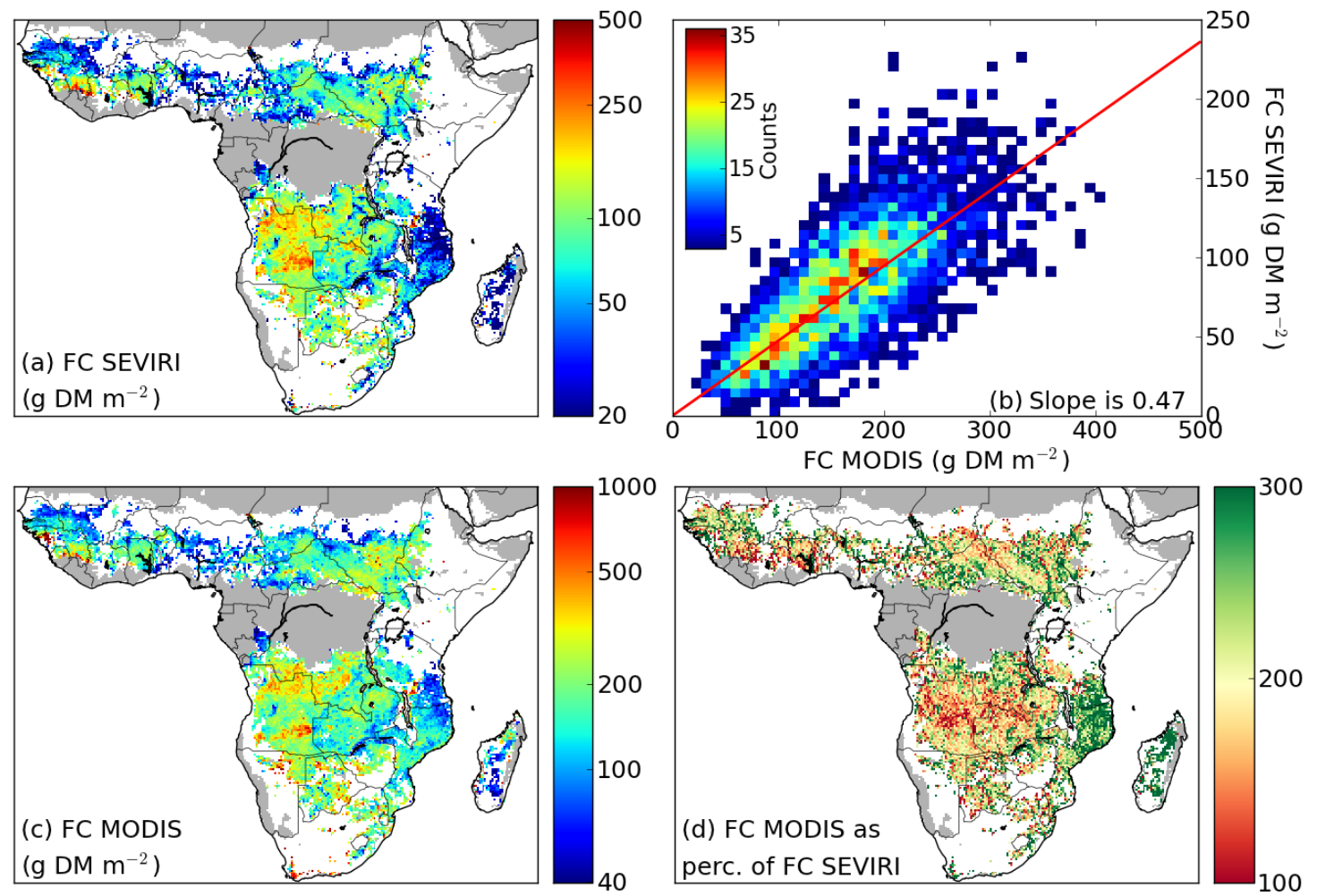

Figure 2. Comparison of fuel consumption (FC) estimates derived by combining FRP and burned-area data. (a) Fuel consumption derived using SEVIRI FRP data. (b) Correlation between fuel consumption estimates based on the SEVIRI and MODIS FRP data. (c) Fuel consumption derived using MODIS FRP data. (d) MODIS-based fuel consumption estimates as a percentage of the SEVIRI-based estimates. For comparison both SEVIRI- and MODIS-based estimates are shown for the same period (2010-2014) and the MODIS FRE data are uncorrected (see Sect. 4.2). Note that on average MODIS-derived FC is about twice as large as SEVIRI-derived FC. Grid cells with dominant land cover "forest" or "bare or sparsely vegetated" were excluded from our analysis and are masked grey, while water and grid cells with less than 50 MODIS FRP detections are shown in white in all figures.

(e.g. Mozambique and Madagascar), likely because of the decreasing sensitivity of the SEVIRI instrument at the greater off-nadir angle over this region (e.g. Freeborn et al., 2014b), and second, the relative fraction of FRE emitted during periods that FRP values were below the SEVIRI detection threshold, a function of the absolute FRP values and the shape of the fire diurnal cycle. Fires with high FRP (related to high fire spread rates and/or fuel consumption) are often equally well observed by both instruments (i.e. red colouring in Fig. 2d), while areas with low fuel consumption are often characterized by a larger differences between the MODIS and SEVIRI estimates (i.e. green colouring in Fig. 2d). To prevent these differences from affecting our estimated correlation too much, we only included frequently burning grid cells (burned area $\geq 15 \% \mathrm{yr}^{-1}$ ) and those that have a surface area of the SEVIRI FRP-PIXEL product grid cells below $12 \mathrm{~km}^{2}$ (minimum value is $9 \mathrm{~km}^{2}$ at nadir) during the linear regression shown in Fig. 2b. This resulted in reasonable correlation $\left(r^{2}=0.42 ; n=6569\right)$. Partial cloud cover and missing data were also affecting the analysis, and we found that $54 \%$ of the annual burned area occurred during periods of reduced data availability (below $80 \%$ during the 15-day time window). When excluding these events, the absolute difference between MODIS- and SEVIRI-based fuel consumption became somewhat smaller (i.e. the slope in Fig. $2 b$ became 0.59), demonstrating that periods of reduced observations were partly responsible for the underestimation in SEVIRIderived fuel consumption. However, by excluding this $54 \%$ of the data, the correlation between MODIS- and SEVIRIbased fuel consumption was reduced $\left(r^{2}=0.28\right)$ due to the heterogeneous nature of fuel consumption.

\subsection{Converting MODIS FRP to fuel consumption using in situ measurements}

Instrument-specific issues may have a large effect on FRE estimates based on satellite remote sensing (see Sect. 4.1 and methods). In order to correct for uncertainties in the MODISderived FRE estimates, we derived a FRE correction factor (1.56) by comparing the uncorrected MODIS-derived fuel consumption to field measurements (Fig. 3a). Due to the limited number of field observations and a number of outliers, the bootstrapped $95 \%$ confidence interval of the correction 
factor ranges from 1.30 to 1.80 . In addition the coefficient of determination $\left(r^{2}\right)$ between both datasets is considered reasonable (0.41), something we return to in the discussion.

Figure $3 \mathrm{~b}$ shows the distribution of MODIS FRP detections for a frequently burning $0.25^{\circ}$ grid cell in northern Africa for the 2003-2014 study period. As discussed in the methods, a single MODIS FRP detection is often not representative of the actual fuel consumption rate or fire activity, and it is more reasonable to take a representative sample (we used a minimum of 50 active fire pixel detections). For this particular $0.25^{\circ}$ grid cell (Fig. 3b), over the full period there were 967 MODIS FRP detections, having a sum of $39.7 \mathrm{GW}$, while total burned area was $5.7 \times 10^{9} \mathrm{~m}^{2}$. During the burning season, the two MODIS instruments together observed the grid cell 2.8 times a day on average. The estimated FRE per unit area burned was therefore $0.22 \mathrm{MJ} \mathrm{m}^{-2}$. After applying the correction factor of 1.56 (see Fig. 3a), the estimated FRE per unit area burned becomes $0.34 \mathrm{MJ} \mathrm{m}^{-2}$ and fuel consumption for the grid cell shown in Fig. $3 \mathrm{~b}$ is $125 \mathrm{~g} \mathrm{DM} \mathrm{m}^{-2}$. To put this value into context, for this grid cell the mean NPP was $732 \mathrm{~g} \mathrm{DM} \mathrm{m}^{-2} \mathrm{yr}^{-1}$ and the mean fire return period 1.75 years over the study period.

Table 1 provides an overview of the field studies used to calibrate the MODIS-based FRE estimates (Fig. 3a), and corresponding $0.25^{\circ}$ fuel consumption estimates based on MODIS FRP detections. Most fuel consumption estimates based on field measurements are similar in magnitude to the ones derived here, although there are a few prominent outliers (numbers 6, 8, 14 and 15). The field studies corresponding to numbers 15 and 16 were carried out within the same $0.25^{\circ}$ grid cell and illustrate that individual case studies are not always directly comparable with our $0.25^{\circ}$ fuel consumption estimates due to the large spatial heterogeneity of fuel consumption.

Fuel consumption for the three study regions was derived by applying the correction factor (Fig. 3a; 1.56 ) to the FRE per unit area burned $\left(\mathrm{MJ} \mathrm{m}^{-2}\right)$ as estimated using the MODIS FRP detections over the full period study period (2003-2014; Fig. 4). South America generally showed relatively high fuel consumption, with the fringes of the deforestation areas having by far the highest values (Fig. 4a). SubSaharan Africa has relatively low fuel consumption compared to Australia and South America, with lowest fuel consumption found in eastern Africa and agricultural regions in western Africa (e.g. Nigeria; cf. Figs. 4b and A1h in the Appendix). Australia shows a surprising pattern where fuel consumption according to our approach in frequently burning savannas in northern Australia appears to be lower than fuel consumption in the drier interior (Figs. $4 \mathrm{c}$ and A1c). The same pattern is observed in some arid regions of southern Africa where fires have long return periods (e.g. Namibia; Figs. $4 \mathrm{~b}$ and A1b).

\subsection{Drivers and dynamics of fuel consumption}

For each continent we assessed whether most fires occurred in productive or low-productivity systems, and whether short or long fire return periods were most common (Fig. 5a-c). Then we explored the distribution of fuel consumption as a function of productivity and fire return periods (Fig. 5d-f), followed by the possible role of land cover type in explaining these patterns (Fig. $5 \mathrm{~g}-\mathrm{i}$ ). We found that biomass burning on the three continents occurred under very different conditions in terms of productivity and fire return periods. Within the South American study region most fires occurred in relatively productive savannas (NPP of $800-1600 \mathrm{~g} \mathrm{DM} \mathrm{m}^{-2} \mathrm{yr}^{-1}$ ) and were characterized by relatively long fire return periods (38 years). Fuel consumption in this region was higher than under similar conditions (in terms of NPP and fire return period) in Sub-Saharan Africa and Australia. African biomass burning was dominated by (woody) savanna fires of annual and biennial return periods which were observed over a wide range of NPP (500-2000 $\mathrm{g} \mathrm{DM} \mathrm{m}^{-2} \mathrm{yr}^{-1}$ ). For the lower productivity African savannas and grasslands, we did not find large differences in fuel consumption between savannas that burn annually or biennially and savannas with somewhat longer return periods (3-8 years). Only African savannas with fire return periods above 8 years showed again a somewhat higher fuel consumption. Strikingly, in the more productive African savannas, fuel consumption declined with longer fire return periods.

In Australia, most burned area occurred in the savannas of intermediate-productivity (500-1200 $\mathrm{g} \mathrm{DM} \mathrm{m}^{-2} \mathrm{yr}^{-1}$ ) and low-productivity hummock grasslands $\left(<500 \mathrm{~g} \mathrm{DM} \mathrm{m}^{-2}\right.$ $\mathrm{yr}^{-1}$; Australian Native Vegetation Assessment, 2001), which were classified as shrublands by the MODIS land cover dataset. While in Sub-Saharan Africa most fires in the lower productivity regions were fuelled by grasses that form well-connected fuel beds, in Australia most fires occurred in poorly connected hummock grasslands that functionally act like shrublands. Both in Sub-Saharan Africa and in Australia, regions classified as shrubs faced longer fire return periods than grasslands and savannas but eventually burned with higher fuel consumption. But even when productivity and fire return periods were similar the fuel consumption in the lowproductivity $\left(<500 \mathrm{~g} \mathrm{DM} \mathrm{m}^{-2} \mathrm{yr}^{-1}\right)$ hummock grasslands of Australia was consistently higher than fuel consumption of the low-productivity grasslands in Sub-Saharan Africa.

Finally, we compared the fuel consumption estimates derived from the MODIS FRP detections (Fig. 4) with fuel consumption estimates of GFED4s. Considerable differences were found between the two approaches (Fig. 6). The fuel consumption estimates derived here resulted in higher fuel consumption estimates for areas of lower productivity, especially those areas dominated by shrublands, while fuel consumption estimates of GFED4s were generally higher in woody savannas, with higher productivity. Interestingly, the 

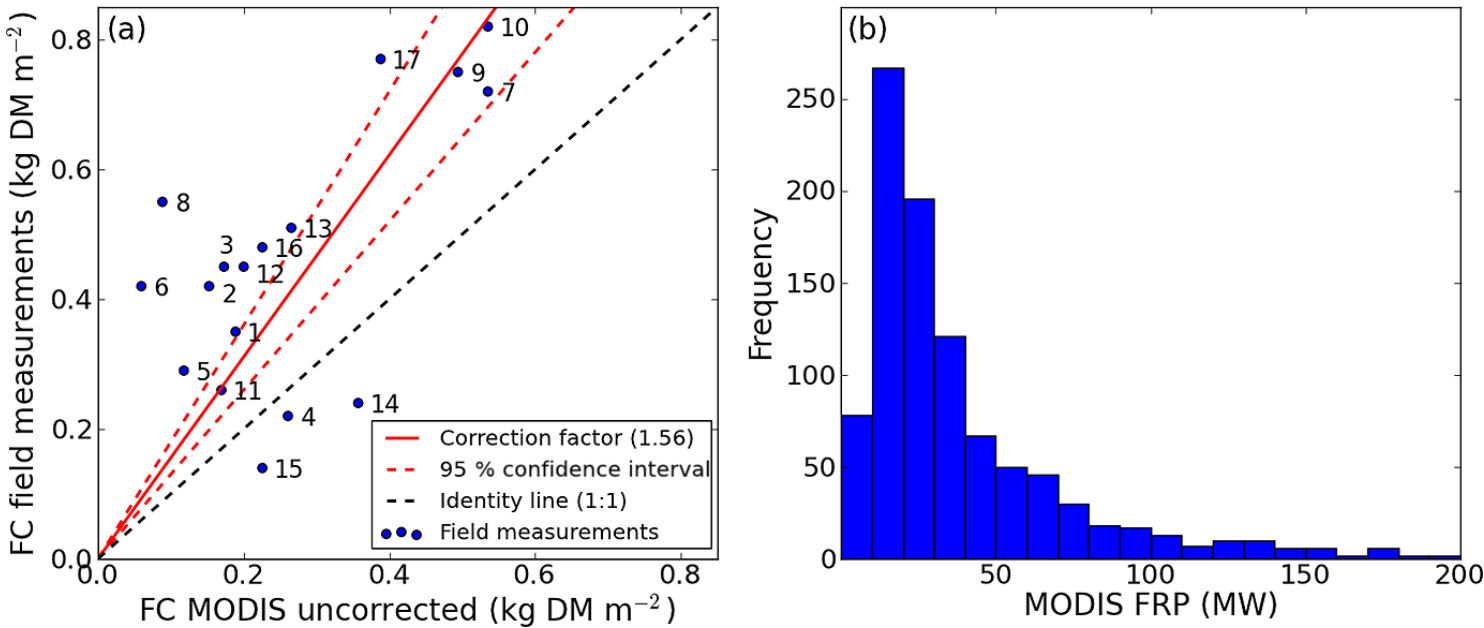

Figure 3. Relationship between MODIS FRP detections and fuel consumption (FC). (a) Comparison of MODIS-derived fuel consumption without correction for uncertainties in the FRE estimates with field measurements of fuel consumption. The slope between the uncorrected MODIS-derived FC and the FC from field measurements (red line; slope is 1.56) is used to correct the MODIS-derived FRE per unit area burned and estimate absolute fuel consumption. The red dashed lines indicate the bootstrapped $95 \%$ confidence interval of the slope (1.301.80), here used as an estimate of uncertainty. The blue dots and numbers refer to the individual field studies (van Leeuwen et al., 2014; Table 1). (b) Distribution of MODIS FRP detections (binned in classes of $10 \mathrm{MW}$ wide) for a frequently burning $0.25^{\circ}$ grid cell in northern Africa $\left(10.00-10.25^{\circ} \mathrm{N}, 24.00-24.25^{\circ} \mathrm{E}\right)$

Table 1. Fuel consumption estimates for grasslands, savannas and woody savannas, based on field studies compiled by van Leeuwen et al. (2014) and the corresponding $0.25^{\circ}$ fuel consumption estimates derived here. For the field studies, numbers in parentheses show the standard deviation. $N$ is the number of active fire detections by MODIS (2003-2014) for each $0.25^{\circ}$ grid cell.

\begin{tabular}{|c|c|c|c|c|c|c|c|}
\hline $\begin{array}{l}\text { No. } \\
\text { (Fig. 3a) }\end{array}$ & Lat & Long & $\begin{array}{l}\mathrm{FC}\left(\mathrm{g} \mathrm{DM} \mathrm{m}^{-2}\right) \\
\text { Field study }\end{array}$ & $\begin{array}{l}\mathrm{FC}\left(\mathrm{g} \mathrm{DM} \mathrm{m}^{-2}\right) \\
\text { MODIS }\end{array}$ & $N$ & Description & Reference \\
\hline 1 & $25.15^{\circ} \mathrm{S}$ & $31.14^{\circ} \mathrm{E}$ & $350(140)$ & 294 & 226 & Lowveld sour bushveld savanna & Shea et al. (1996) and Ward et al. (1996) \\
\hline 2 & $12.35^{\circ} \mathrm{S}$ & $30.21^{\circ} \mathrm{E}$ & $420(100)$ & 237 & 1487 & Dambo, miombo, chitemene & Shea et al. (1996) and Ward et al. (1996) \\
\hline 3 & $16.60^{\circ} \mathrm{S}$ & $27.15^{\circ} \mathrm{E}$ & $450(-)$ & 269 & 216 & Semi-arid miombo & Shea et al. (1996) and Ward et al. (1996) \\
\hline 4 & $14.52^{\circ} \mathrm{S}$ & $24.49^{\circ} \mathrm{E}$ & $220(120)$ & 405 & 880 & Dambo and miombo & Hoffa et al. (1999) \\
\hline 5 & $15.00^{\circ} \mathrm{S}$ & $23.00^{\circ} \mathrm{E}$ & $290(90)$ & 183 & 407 & Dambo and floodplain & Hély et al. (2003b) \\
\hline 6 & $12.22^{\circ} \mathrm{N}$ & $2.70^{\circ} \mathrm{W}$ & $420(70)$ & 92 & 177 & Grazing and no grazing & Savadogo et al. (2007) \\
\hline 7 & $15.84^{\circ} \mathrm{S}$ & $47.95^{\circ} \mathrm{W}$ & $720(90)$ & 832 & 126 & Different types of cerrado & Ward et al. (1992) \\
\hline 8 & $8.56^{\circ} \mathrm{N}$ & $67.25^{\circ} \mathrm{W}$ & $550(190)$ & 138 & 232 & Protected savanna for 27 years & Bilbao and Medina (1996) \\
\hline 9 & $15.51^{\circ} \mathrm{S}$ & $47.53^{\circ} \mathrm{W}$ & $750(-)$ & 768 & 69 & Campo limpo and campo sujo & Miranda et al. (1996) \\
\hline 10 & $15.84^{\circ} \mathrm{S}$ & $47.95^{\circ} \mathrm{W}$ & $820(280)$ & 832 & 126 & Different types of cerrado & De Castro and Kauffman (1998) \\
\hline 11 & $3.75^{\circ} \mathrm{N}$ & $60.50^{\circ} \mathrm{W}$ & $260(90)$ & 263 & 35 & Different types of cerrado & Barbosa and Fearnside (2005) \\
\hline 12 & $12.40^{\circ} \mathrm{S}$ & $132.50^{\circ} \mathrm{E}$ & $450(130)$ & 311 & 1885 & Woodland & Cook et al. (1994) \\
\hline 13 & $12.30^{\circ} \mathrm{S}$ & $133.00^{\circ} \mathrm{E}$ & $510(-)$ & 413 & 1277 & Tropical savanna & Hurst et al. (1994) \\
\hline 14 & $12.43^{\circ} \mathrm{S}$ & $131.49^{\circ} \mathrm{E}$ & $240(110)$ & 555 & 433 & Grass and woody litter & Rossiter-Rachor et al. (2008) \\
\hline 15 & $12.38^{\circ} \mathrm{S}$ & $133.55^{\circ} \mathrm{E}$ & $140(160)$ & 351 & 1357 & Early and late season fires & Russell-Smith et al. (2009) \\
\hline 16 & $12.38^{\circ} \mathrm{S}$ & $133.55^{\circ} \mathrm{E}$ & $480(-)$ & 351 & 1357 & Grass and open woodland & Meyer et al. (2012) \\
\hline 17 & $17.65^{\circ} \mathrm{N}$ & $81.75^{\circ} \mathrm{E}$ & $770(260)$ & 603 & 20 & Woodland & Prasad et al. (2001) \\
\hline
\end{tabular}

best comparison was found in zones of most frequent fire and short fire return periods (compare Fig. 6 with Fig. A1a-c).

\section{Discussion}

Understanding the global distribution of fuel consumption per unit area burned, here referred to as fuel consumption for brevity, and fuel build-up mechanisms is important for making landscape management decisions, understanding the implications of changes in climate or vegetation patterns on fire dynamics, and deriving accurate fire emission estimates. Boschetti et al. (2009) and Roberts et al. (2009, 2011) showed that fuel consumption estimates can be derived from combining burned-area and active fire satellite products. Here we build upon their approaches and derived fuel consumption estimates for regions of low tree cover in South America, Sub-Saharan Africa and Australia, and explored the drivers of the spatial distribution. Following previous studies, we found that fuel consumption is highly 

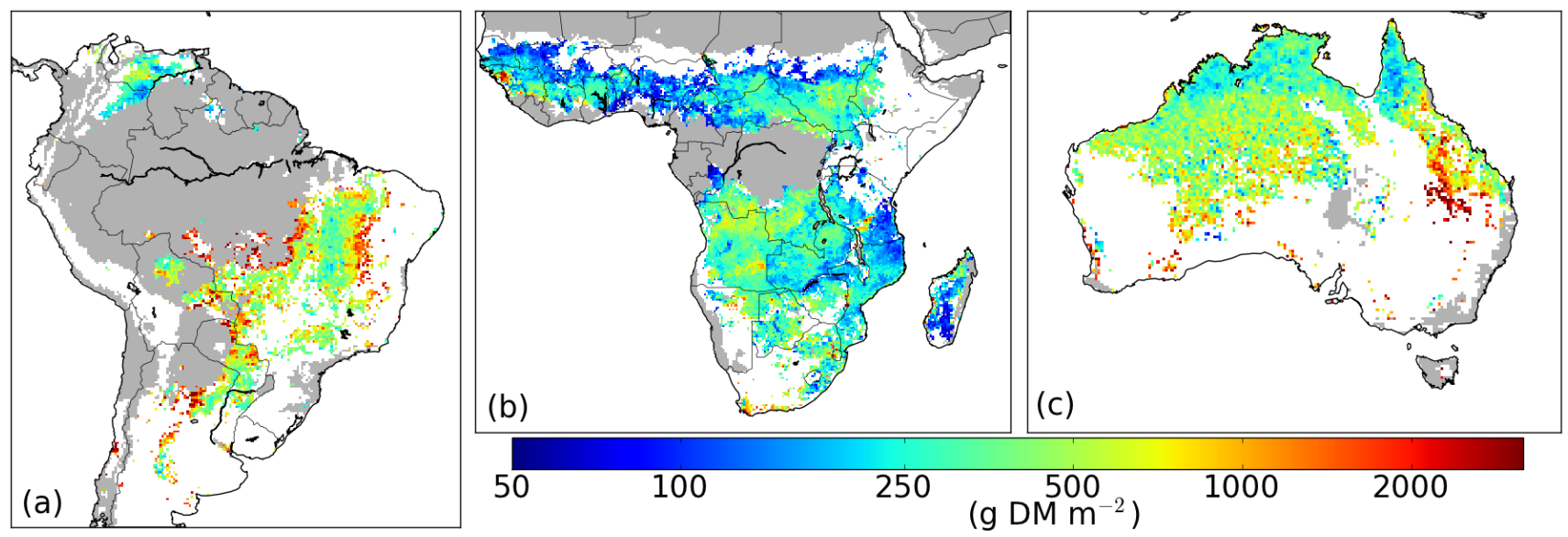

Figure 4. Distribution of fuel consumption based on MODIS-derived FRE per unit of area burned (2003-2014) and calibrated against field studies. (a) South America, (b) Sub-Saharan Africa and (c) Australia.

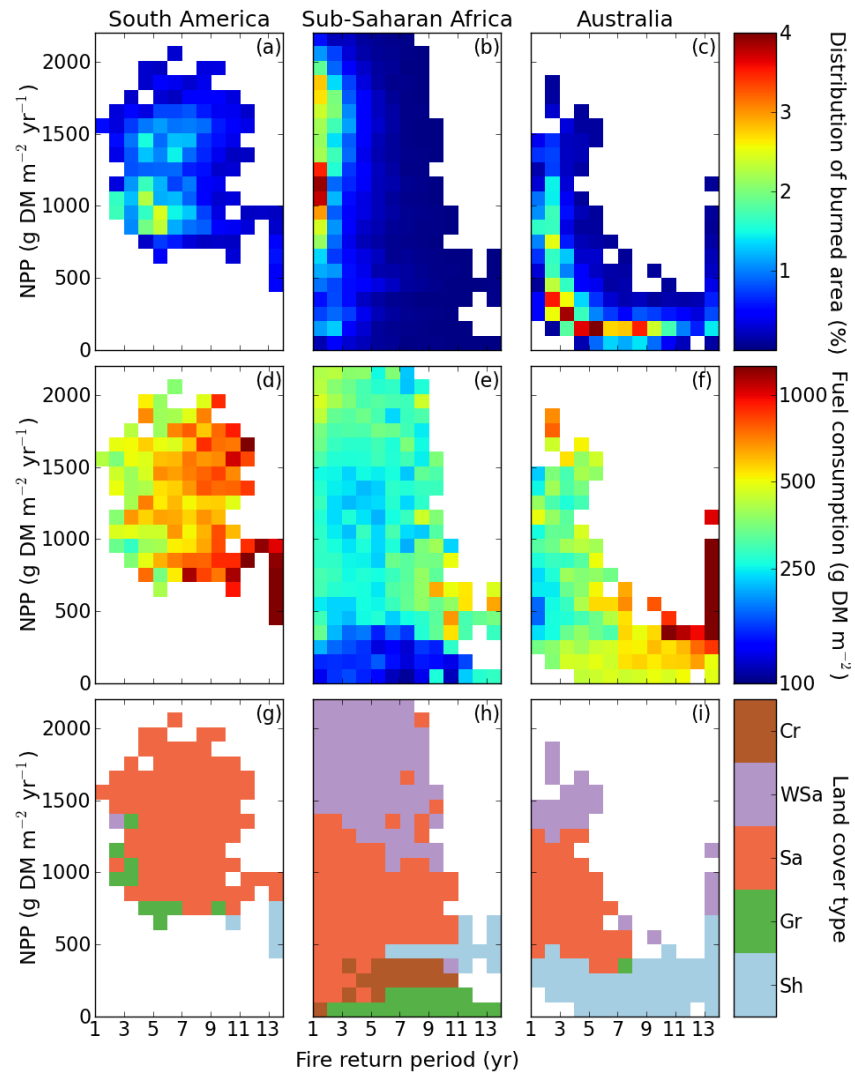

Figure 5. Distribution of burned area (a-c), fuel consumption (df) and dominant land cover type ( $\mathbf{g}-\mathbf{i})$, all binned as a function of fire return periods and net primary productivity (NPP) for the three study regions (South America, Sub-Saharan Africa and Australia). Bins with burned area below $500 \mathrm{~km}^{2} \mathrm{yr}^{-1}$ are masked in white. Abbreviations of land cover type stand for cropland (Cr), woody savanna (WSa), savanna (Sa), grassland (Gr) and shrubland (Sh). heterogeneous (e.g. Boschetti and Roy, 2009; Hély et al., 2003a; Roberts et al., 2011; Savadogo et al., 2007). Consequently, obtaining representative field measurements is labour-intensive, and only a limited number of studies have been carried out (van Leeuwen et al., 2014). Satellite-derived estimates of the spatial distribution of fuel consumption can therefore form an important addition to the scarce field measurements and may guide future field campaigns.

Here we discuss the pros and cons of the fuel consumption estimates presented in this paper and the current challenges for such an exercise (Sect. 5.1). We then discuss the drivers of fuel consumption in the three study regions, and compare the results found here to fuel consumption estimates of the GFED4s data (Sect. 5.2).

\subsection{Satellite-derived fuel consumption estimates}

In this study we explored the distribution of fuel consumption beyond the geostationary position of the SEVIRI instrument and developed a method based on FRP detections of the polar-orbiting MODIS instruments. Both geostationary and polar-orbiting instruments have advantages: the geostationary SEVIRI instrument observes the full fire diurnal cycle, while the polar-orbiting MODIS instruments only provide observations at certain fixed hours of the day, potentially leading to structural errors in the FRE estimates (Andela et al., 2015; Ellicott et al., 2009; Freeborn et al., 2011; Vermote et al., 2009). However, the sensitivity of the MODIS instruments to small and more weakly burning fires is much larger than that of the SEVIRI instrument (Freeborn et al., 2014b). In order to get a better understanding of the implications of these differences, we compared the fuel consumption estimates based on both platforms using the FREto-DM-burned conversion factor found during laboratory experiments (Wooster et al., 2005). At first sight, very similar spatial patterns were found using polar-orbiting or geosta- 
tionary data (compare Fig. 2a and c), providing confidence in the spatial distribution of the fuel consumption estimates. However, many differences were also present (Fig. 2d). We found that a large part of the differences could be attributed to the different sensors characteristics and methods used here. The shape of the fire diurnal cycle, for example, affects both MODIS-based fuel consumption estimates due to the limited number of daily overpasses but also the SEVIRI-derived fuel consumption estimates because it directly affects the relative fraction of daily fire activity that falls below the SEVIRI detection threshold. After excluding grid cells at higher off-nadir angles of the SEVIRI instrument and of infrequent fire occurrence, we found an $r^{2}$ of 0.42 between both approaches. Finally, a large structural difference was observed, and SEVIRI-derived fuel consumption was about half of the MODIS-derived fuel consumption. Such structural differences likely occur due to the different sensitivities of the instruments (Freeborn et al., 2009, 2014b). As compared to the MODIS instruments, the SEVIRI instrument likely underestimates fire activity in areas where a relatively large fraction of fire activity falls below the detection threshold (e.g. small fires, or fires partly obscured by trees; as discussed by Freeborn et al., 2009, 2014b, Roberts and Wooster, 2008 and Roberts et al., 2011). In our analysis a small part of the structural difference could also be explained by the fact that we did not correct for cloud cover and/or missing data in the SEVIRI-based FC estimates. Not surprisingly, the best comparison between both methods was found in areas of high fuel consumption rates (Fig. 2d), for example areas where fires can spread over large areas to form large fire fronts (Archibald et al., 2013), and areas of high fuel consumption; these fires with high FRP are likely to be well observed by both instruments.

When deriving fuel consumption estimates based on the SEVIRI instrument, Roberts et al. (2011) found fuel consumption estimates around 3.5 times lower than modelled values of GFED3.1 (van der Werf et al., 2010). Other studies that calculated fire emissions using the SEVIRI instrument found similar low estimates compared to GFED (e.g. Roberts and Wooster, 2008). Following previous studies, we find that about half of this discrepancy can be attributed to SEVIRI failing to detect the more weakly burning fires that ultimately are responsible for around half of the emitted FRE (Freeborn et al., 2009, 2014b). Similarly, MODIS-derived FRE estimates are also affected by the sensor characteristics and methods used here. We therefore decided to correct for such issues by calibrating the FRE per unit area burned based on the MODIS instruments directly against field observations before converting them to fuel consumption. When using the conversion factor found by Wooster et al. (2005) and the uncorrected MODIS FRE estimates, a slope of 1.56 was found during linear regression between MODIS-derived fuel consumption and fuel consumption estimates based on field measurements (Fig. 3a). Because of the large spatiotemporal variation in fuel consumption and the relatively low sample size, the $95 \%$ confidence interval of the bootstrapped correction factor was 1.30-1.80. The uncertainty associated with the correction factor is thus around $\pm 16 \%$, although other factors may further affect the uncertainty in our fuel consumption estimates as discussed below. The need for a FRE correction factor (1.56) may for a large part be explained by sensor-specific limitations (Giglio et al., 2006a) that likely lead to underestimations of total FRE, particularly due to the reduced sensitivity of the MODIS instruments towards the swath edges (Freeborn et al., 2011). The fire diurnal cycle in combination with the timing of the MODIS overpasses and partial cloud cover may also have affected absolute FRE estimates and thus the FRE correction factor derived here (Andela et al., 2015). Although Freeborn et al. (2011) find a similar correction to be needed due to the decreasing sensor sensitivity with increasing scan angle, the number of field measurements was limited and our calibration was strongly influenced by a few field studies in more productive savannas. The correlation of the field observations and the $0.25^{\circ}$ long-term average fuel consumption estimates derived here (Fig. 3a; $r^{2}=0.41$ ) was affected by various factors. Most importantly, fuel consumption is both spatially and temporarily highly heterogeneous (e.g. Govender et al., 2006; Hély et al., 2003a; Hoffa et al., 1999), so even in the case of accurate fuel consumption estimates from both field measurements and from satellite, large scatter is likely observed. In addition, the fuel consumption estimates derived here are mostly representative of midday burning during the peak burning season because FRE emitted during these periods will dominate the signal. Finally, direct comparison with the field studies was impossible because most field studies were carried out before the launch of the MODIS and SEVIRI instruments (van Leeuwen et al., 2014).

Given the large scale at which landscape fires occur and the high spatiotemporal variation in fuel consumption, satellite-derived fuel consumption estimates are crucial to get a better system understanding. While different satellitederived fuel consumption estimates resulted in a similar spatial distribution, the absolute fuel consumption estimates remained more uncertain. This study clearly demonstrated the potential to derive fuel consumption estimates by combining satellite-derived FRP and burned area. However, deriving accurate FRE estimates is difficult due to several sensorspecific limitations. Here we choose to calibrate against field observations, correcting for such errors. Better understanding of for example the effect of tree cover on FRP detections would allow for expansion of such methods beyond open land cover types. Validation of the satellite-derived products by specifically designed field campaigns aiming, for example, at NPP or fire return period transects or high-resolution airborne remote sensing may further improve our understanding of the active fire sensor characteristics and provide more confidence in absolute fuel consumption estimates in the future. 


\subsection{Drivers and dynamics of fuel consumption}

Fuel consumption depends on the amount of fuel available for burning and the combustion completeness. In arid areas available fuel and thus fuel consumption are often limited by precipitation. Across these arid and semi-arid areas precipitation generally determines vegetation productivity and tree cover. Grasses in these more arid ecosystems often have a combustion completeness above $80 \%$ (van Leeuwen et al., 2014), and fuel consumption and fuel loads will generally be similar. In more humid regions, however, fuel moisture may limit fuel consumption by lowering fire spread and the combustion completeness (Stott, 2000; van der Werf et al., 2008). In our three study regions (South America, Sub-Saharan Africa and Australia) fires occurred under very different conditions in terms of NPP and fire return periods (Fig. 5a-c), partially as a result of the different distributions of NPP across the study regions. In South America most burned area occurred in regions with fire return periods between 3 and 8 years and intermediate productivity $\left(800-1600 \mathrm{~g} \mathrm{DM} \mathrm{m}^{-2} \mathrm{yr}^{-1}\right.$ ). In Africa the vast majority of burned area was found in areas with short fire return periods ( $1-3$ years) and a wide range of productivity $\left(500-2000 \mathrm{~g} \mathrm{DM} \mathrm{m}^{-2} \mathrm{yr}^{-1}\right)$. In Australia the majority of fires occurred in the more arid low-productivity zones $\left(<500 \mathrm{~g} \mathrm{DM} \mathrm{m}^{-2} \mathrm{yr}^{-1}\right)$, while annually burning regions were uncommon and restricted to the humid higher productivity zones (typical fire return periods were in the range 2 to 10 years). Although climate and vegetation shape the boundary conditions for fires to occur, most ignitions are of human origin (Archibald et al., 2012; Scholes and Archer, 1997; Scholes et al., 2011; Stott, 2000) and the differences between the continents are expected to be partly the result of different management practices. Overall, a pattern of increasing fuel consumption towards more productive regions and longer return periods was observed (Fig. 5d-f). Consequently, fuel consumption in Africa, with short return periods, was relatively low compared to Australia or South America. However, increases in fuel consumption with increasing time between fires and NPP were far from linear and other drivers also played a large role (e.g. Shea et al., 1996).

In more arid regions, we found a clear difference between ecosystems where most fuel exists of grasses opposed to regions that were classified as shrubs. In Africa, the regions with NPP below $500 \mathrm{~g} \mathrm{DM} \mathrm{m}^{-2} \mathrm{yr}^{-1}$ are dominated by savannas or grasslands, while in Australia these regions are classified as shrubs (Fig. 5h and i). In the specific case of Australia, much of the interior is actually dominated by hummock grasslands (rather than shrubs), grasses that functionally act like shrubs (Australian Native Vegetation Assessment, 2001) and are therefore classified as being shrublands in the University of Maryland classification. Grasses may form well-connected fuel beds, resulting in short (often annual or biennial) fire return periods (Archibald et al., 2013;
Beerling and Osborne, 2006; Scholes and Archer, 1997), while fire return periods in shrublands (or hummock grasslands) were generally longer (Fig. 5). But on top of the differences in fire return periods between these low-productivity ecosystems, the grass species that were dominant in most of Africa showed a rather slow fuel build-up compared to shrubs or the Australian hummock grasses even when fire return periods and productivity were similar (Fig. 5e and f). A possible explanation for the relatively slow fuel build-up in African grasslands and savannas as opposed to Australian hummock grasslands and shrublands could be grazing by livestock or wildlife and human management (Savadogo et al., 2007; Scholes et al., 2011). Shea et al. (1996) report a large impact of wildlife, ranging from insects to grazers, on fuel build-up processes in various study sites in Africa, and such effects will differ among continents given that neither South America nor Australia have the diverse and dominant mega-herbivore fauna of Africa. Other differences may come from non-fire-related decomposition rates, which depend on plant species and climate (Gupta and Singh, 1981).

In the more productive savannas marked differences were observed between the different continents (Fig. 5). Africa was unique when it comes to its short fire return periods, even in highly productive ecosystems. In African savannas of intermediate productivity $\left(500-1500 \mathrm{~g} \mathrm{DM} \mathrm{m}^{-2} \mathrm{yr}^{-1}\right)$, fuel build-up with time appeared slow compared to the other continents. These differences may originate from differences of grazing pressure or the occurrence of different species, as discussed above, but may also be related to management practices or climate. For example, the highest fuel consumption in the more humid African savannas was found in the most frequently burning grid cells, suggesting a high combustion completeness. In areas where burning is largely limited by fuel humidity, the combustion completeness may have a considerable impact on fuel consumption. The fact that both frequently burning and almost fire-free areas occur under similar climatic conditions in (sub)tropical savannas suggests that fuel conditions are important, while frequent fire occurrence may enhance flammability (Shea et al., 1996; Ward et al., 1996). Short fire return periods provide a competitive advantage to herbaceous vegetation over woody vegetation (Bond, 2008; Bond et al., 2005). A high degree of canopy openness will result in more grass-covered area and higher dry season ground surface temperatures and lower fuel moisture content, resulting in high combustion completeness. However, a similar temperature- or moisturedriven effect may also be caused by the timing of the ignitions (Hoffa et al., 1999) directly related to management practices. Le Page et al. (2010) showed that African savannas typically burn early in the dry seasons, while Australian savannas often burn later in the season. Finally, the above assumes a stable situation of tree cover density and biomass over the study period, while in some regions there is tree cover loss due to decreased fire return periods or land use change over our relatively short study period, while other ar- 

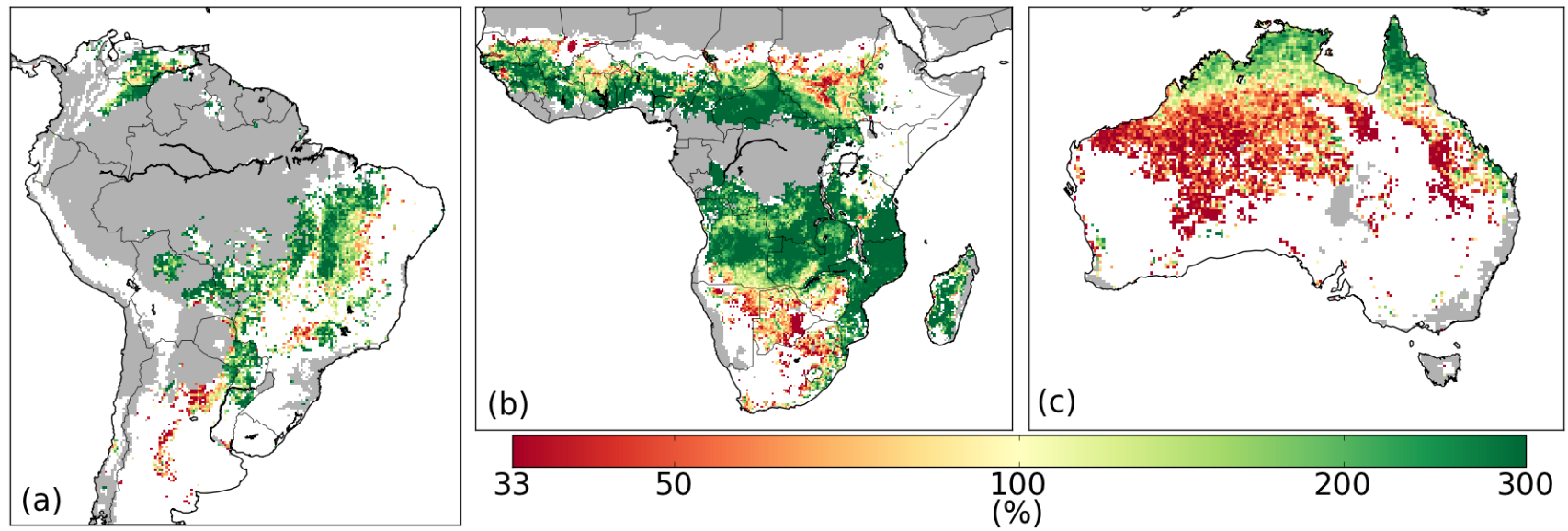

Figure 6. Fuel consumption estimated by GFED4s as a percentage of fuel consumption derived here (based on MODIS-derived FRE, calibrated against in situ measurements). (a) South America, (b) Sub-Saharan Africa and (c) Australia.

eas are experiencing increases in tree cover (Wigley et al., 2010). A clear example was South America, where the apparent fuel build-up (Fig. 5d) appears largely driven by high fuel consumption in active deforestation areas (Fig. 4; see Hansen et al., 2013). The effect of human management on fuel loads was also clearly visible in Africa's agricultural areas (e.g. Nigeria), where fuel loads were typically low (Figs. 4, 5e and $\mathrm{h}$ ).

Finally, the fuel consumption estimates derived here were compared to the modelled fuel consumption estimates of GFED4s. Within GFED fuel build-up is largely driven by NPP and fire return periods, while biomass build-up is distributed over two different pools: herbaceous and woody (van der Werf et al., 2010). This differentiation is important, because in savanna ecosystems most fires burn in the grass layer, leaving the older well-established woody vegetation largely untouched (Scholes and Archer, 1997). Fuel consumption estimates derived here and by GFED were comparable in annual or biennial burning savannas (Figs. 6 and A1a-c). This is encouraging, because from an emissions perspective the modelling of fuel consumption has to be most accurate in areas that burn annually or biennially where little long-term fuel build-up takes place. For arid areas in general, but especially for shrublands and the hummock grasslands in Australia, the fuel consumption estimates derived here were considerably larger than the ones estimated by GFED. Part of this difference may be caused by GFED using a universal fuel build-up mechanism for all types of grasses and shrublands (van der Werf et al., 2010), which according to our findings seems oversimplified. In fact, hummock grasses act like shrubs with bare soil between the mounds of hummock grass (Australian Native Vegetation Assessment, 2001); such behaviour likely results in very different fuel build-up dynamics which may vary strongly depending on the wet season intensity as opposed to other grasses that form a well-connected fuel bed. The enhanced fuel consumption in arid and semi- arid drylands found here confirms the important role of arid and semi-arid drylands in the inter-annual variability in the global carbon cycle (Poulter et al., 2014).

In more humid regions, with higher woody cover, the fuel consumption estimates of GFED4s were higher than the ones derived here. Within GFED it is assumed that the amount of woody vegetation burned is a function of tree cover within savannas and woody savannas (van der Werf et al., 2010). It remains unclear to what extent the woody vegetation in savannas burns. Although fires greatly reduce the occurrence of trees in many savannas (Bond, 2008; Bond et al., 2005), field studies often report that the established woody vegetation in savannas is rather resistant to fire (Scholes et al., 2011). The potential tree cover for a given area is directly related to mean annual precipitation (Sankaran et al., 2005), although it is further affected by, for example, the occurrence of different species (Lehmann et al., 2014) or availability of nutrients (Bond, 2008). In the tropics highest precipitation is generally found with decreasing dry season duration and may thus prevent fires from spreading to the woody fraction of the vegetation. Moreover, typical architecture of savanna trees varies considerably between continents affecting their sensitivity to fire (Lehmann et al., 2014; Moncrieff et al., 2014). While some woody species may be better adjusted to relatively cool frequent fires with low fuel loads, most common in frequently burning and/or well-grazed grasslands of Africa, other species are better adjusted to more intense and infrequent fire occurrence. Although fuel consumption estimates based on FRP detections may be affected by tree cover to some extent (Freeborn et al., 2014b), active deforestation areas in South America clearly stand out because of their high fuel consumption. We expect that during future studies satellite-derived fuel consumption estimates may help to differentiate between grass-fuelled fires and fires that additionally burn part of the woody cover. Moreover, satellite-derived fuel consumption estimates could be used as a reference for 
biogeochemical models, while providing improved insights into the underlying processes.

\section{Conclusions}

Satellite-derived fuel consumption estimates (with units of kilograms of dry matter per square metre burned) provide a unique opportunity to challenge current understanding of spatiotemporal variation in fuel consumption that to date is mostly based on field studies and modelling. The fuel consumption estimates based on fire radiative power (FRP) data of the geostationary SEVIRI and polar-orbiting MODIS instruments showed good agreement in terms of spatial patterns, suggesting that these estimates were generally robust. When converting fire radiative energy (FRE) estimates derived from MODIS and SEVIRI to fuel consumption using a conversion factor based on laboratory measurements and mapped burned area, fuel consumption estimates based on MODIS FRP data were about twice as high as the ones based on the SEVIRI data. This can likely be attributed to SEVIRI failing to detect large parts of the emitted FRE by more weakly burning or (highly numerous) smaller fires, which ultimately are responsible for around half of the emitted FRE. On top of that, when we calibrated the fuel consumption estimates based on MODIS FRP detections to field observations, we found that a correction factor of 1.56 was needed for them to match. This discrepancy likely stems from underestimation of FRE based on the MODIS instruments, for example related to the decreased sensitivity of the instruments towards the swath edges. Our best estimates of fuel consumption based on MODIS-derived FRE using the correction factor based on field observations were similar in magnitude to modelled fuel consumption estimates from GFED4s, but discrepancies were found in the spatial patterns. However, the limited number of field studies combined with the high spatiotemporal heterogeneity of fuel consumption complicated the comparison of field studies with long-term, coarse-scale satellite-derived products, and uncertainty in absolute estimates remained therefore considerable. Field studies especially designed to validate satellite-derived fuel consumption estimates, aiming for example at NPP or fire return period transects, possibly using air-based remote sensing, could improve (confidence in) absolute fuel consumption estimates in the future.
Dominant biomass burning conditions in South America, Sub-Saharan Africa and Australia were highly different in terms of NPP and fire return periods, partly driving fuel consumption patterns. In South America most fires occurred in savannas with relatively long fire return periods, resulting in relatively high fuel consumption compared to the other study regions. In contrast, most burned area in Sub-Saharan Africa stemmed from (woody) savannas that burned annually or biennial with relatively low fuel consumption. Australian biomass burning was dominated by relatively unproductive (hummock) grasslands with a wide range of fire return periods, while savannas with fire return periods of $2-3$ years also contributed.

Besides NPP and fire return periods, vegetation type played an important role in determining the fuel buildup mechanism. Grasslands favoured short fire return periods and were generally characterized by low fuel buildup rates. Shrublands, or grassy species that functionally act like shrubs, on the other hand, were generally characterized by longer return periods, but gradual fuel build-up occurred over the years eventually leading to higher fuel consumption. Similarly, land management had a marked effect on fuel consumption. In the major deforestation regions of South America, fires consumed woody biomass during the MODIS era, increasing fuel consumption estimates. Western African fuel consumption was clearly suppressed in some areas, likely associated with agriculture and/or grazing. These results demonstrate that the modelling of fuel consumption is complex, while the relation between climate, vegetation and fuel consumption may vary across the continents depending on, for example, the presence of certain species. During future investigations, satellite-derived fuel consumption estimates may be used as a reference dataset for biochemical models and may help to better understand the interaction between climate, vegetation patterns, landscape management and fuel consumption.

\section{Data availability}

All data are publicly available and are described in detail in the data section, data can be accessed using the following links http://modis-fire.umd.edu, http://landsaf.meteo.pt, http: //reverb.echo.nasa.gov and http://globalfiredata.org. 


\section{Appendix A}
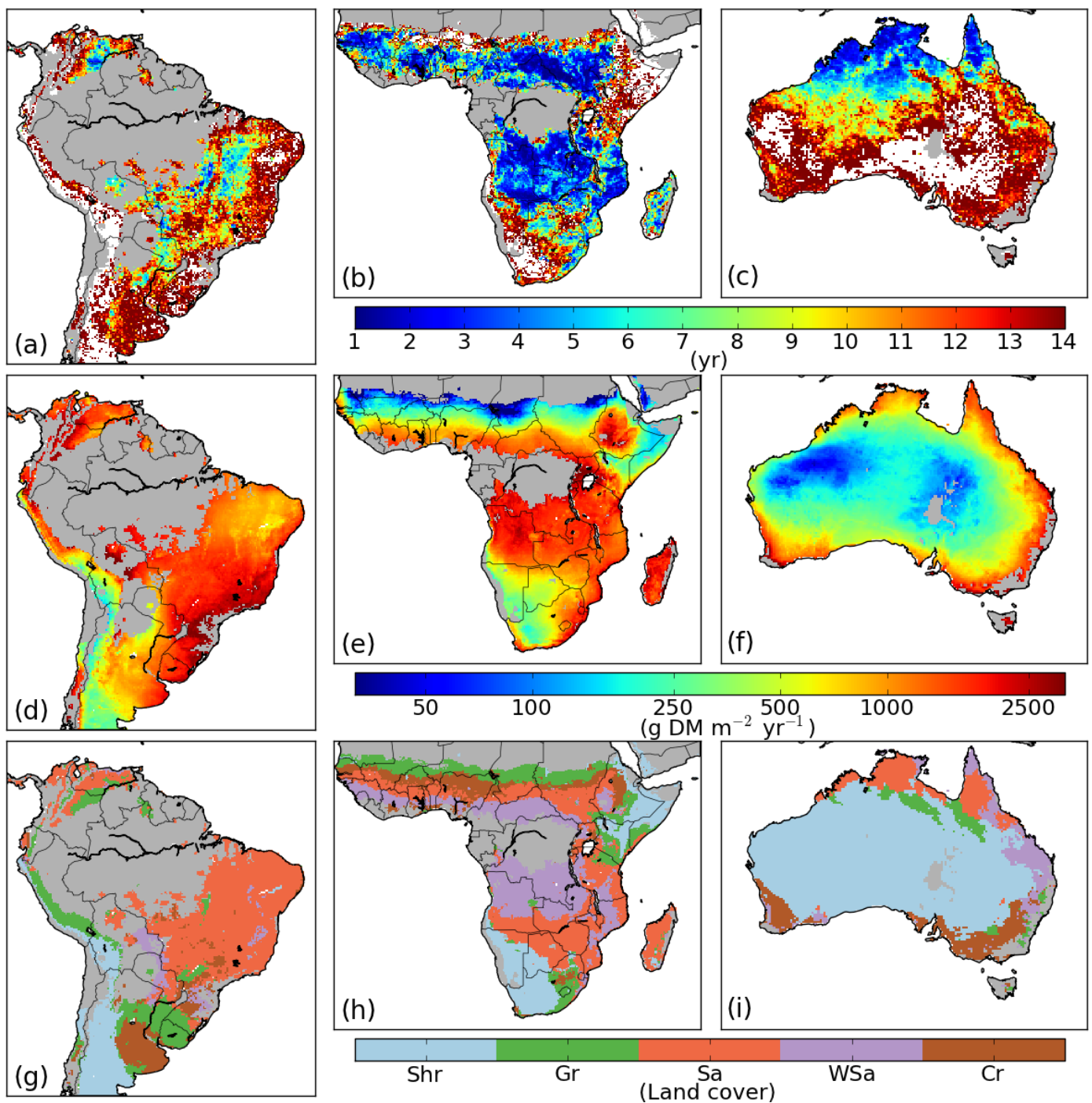

Figure A1. Spatial distribution of parameters affecting fuel consumption dynamics. (a-c) Fire return periods for South America, Sub-Saharan Africa and Australia, respectively; (d-f) net primary productivity for South America, Sub-Saharan Africa and Australia, respectively; and (g-i) dominant land cover type for South America, Sub-Saharan Africa and Australia, respectively. Grid cells with dominant land cover "forest" or "bare or sparsely vegetated" were excluded from our analysis and are masked grey, while water is shown in white. Abbreviations of land cover type stand for cropland (Cr), woody savanna (WSa), savanna (Sa), grassland (Gr) and shrubland (Sh). 
Acknowledgements. The authors would like to thank the two reviewers for their constructive remarks and the data providing agencies (NASA and EUMETSAT LSA SAF) for making their data publicly available. This study was funded by the EU in the FP7 and H2020 projects MACC-II and MACC-III (contract nos. 283576 and 633080) and the European Research Council (ERC), grant number 280061 .

Edited by: K. Thonicke

\section{References}

Andela, N. and van der Werf, G. R.: Recent trends in African fires driven by cropland expansion and El Niño to La Niña transition, Nature Climate Change, 4, 791-795, 2014.

Andela, N., Kaiser, J. W., van der Werf, G. R., and Wooster, M. J.: New fire diurnal cycle characterizations to improve fire radiative energy assessments made from MODIS observations, Atmos. Chem. Phys., 15, 8831-8846, doi:10.5194/acp-15-88312015, 2015.

Andreae, M. and Merlet, P.: Emission of trace gases and aerosols from biomass burning, Global Biogeochem. Cy., 15, 955-966, 2001.

Aouizerats, B., van der Werf, G. R., Balasubramanian, R., and Betha, R.: Importance of transboundary transport of biomass burning emissions to regional air quality in Southeast Asia during a high fire event, Atmos. Chem. Phys., 15, 363-373, doi:10.5194/acp-15-363-2015, 2015.

Archibald, S., Roy, D. P., van Wilgen, B. W., and Scholes, R. J.: What limits fire? An examination of drivers of burnt area in Southern Africa, Glob. Change Biol., 15, 613-630, 2009.

Archibald, S., Scholes, R. J., Roy, D. P., Roberts, G., and Boschetti, L.: Southern African fire regimes as revealed by remote sensing, Int. J. Wildland Fire, 19, 861-878, 2010.

Archibald, S., Staver, A. C., and Levin, S. A.: Evolution of humandriven fire regimes in Africa, P. Natl. Acad. Sci. USA, 109, 847852, 2012.

Archibald, S., Lehmann, C. E. R., Gómez-Dans, J. L., and Bradstock, R. A.: Defining pyromes and global syndromes of fire regimes, P. Natl. Acad. Sci. USA, 110, 6442-6447, 2013.

Australian Native Vegetation Assessment: National Land and Water Resources Audit, Canberra, Australia, 2001.

Barbosa, R. I. and Fearnside, P. M.: Above-ground biomass and the fate of carbon after burning in the savannas of Roraima, Brazilian Amazonia, Forest Ecol. Manag., 216, 295-316, 2005.

Beerling, D. J. and Osborne, C. P.: The origin of the savanna biome, Glob. Change Biol., 12, 2023-2031, 2006.

Bilbao, B. and Medina, E.: Types of grassland fires and nitrogen volatilization in tropical savannas of Venezuela, in: Biomass burning and global change: Biomass burning in South America, Southeast Asia, and temperate and boreal ecosystems and the oil fires of Kuwait, edited by: Levine, J. S., 1996.

Bond, W. J.: What Limits Trees in $\mathrm{C}_{4}$ Grasslands and Savannas?, Annu. Rev. Ecol. Evol. S., 39, 641-659, 2008.

Bond, W. J., Woodward, F. I., and Midgley, G. F.: The global distribution of ecosystems in a world without fire, New Phytol., 165, 525-537, 2005
Boschetti, L. and Roy, D. P.: Strategies for the fusion of satellite fire radiative power with burned area data for fire radiative energy derivation, J. Geophys. Res., 114, D20302, doi:10.1029/2008JD011645, 2009.

Boschetti, L., Roy, D. P., Justice, C. O., and Giglio, L.: Global assessment of the temporal reporting accuracy and precision of the MODIS burned area product, Int. J. Wildland Fire, 19, 705-709, 2010.

Bowman, D. M. J. S., Balch, J. K., Artaxo, P., Bond, W. J., Carlson, J. M., Cochrane, M. A., D'Antonio, C. M., Defries, R. S., Doyle, J. C., Harrison, S. P., Johnston, F. H., Keeley, J. E., Krawchuk, M. A., Kull, C. A., Marston, J. B., Moritz, M. A., Prentice, I. C., Roos, C. I., Scott, A. C., Swetnam, T. W., van der Werf, G. R., and Pyne, S. J.: Fire in the Earth system, Science, 324, 481-484, 2009.

Chen, Y., Morton, D. C., Jin, Y., Gollatz, G. J., Kasibhatla, P. S., van der Werf, G. R., Defries, R. S., and Randerson, J. T.: Long-term trends and interannual variability of forest, savanna and agricultural fires in South America, Carbon Manag., 4, 617-638, 2013.

Cook, G. D.: The fate of nutrients during fires in a tropical savanna, Aust. J. Ecol., 19, 359-365, 1994.

Crutzen, P. J., Heidt, L. E., Krasnec, J. P., Pollock, W. H., and Seiler, W.: Biomass burning as a source of atmospheric gases $\mathrm{CO}, \mathrm{H}_{2}$, $\mathrm{N}_{2} \mathrm{O}, \mathrm{NO}, \mathrm{CH}_{3} \mathrm{Cl}$ and COS, Nature, 282, 253-256, 1979.

De Castro, E. A. and Kauffman, J. B.: Ecosystem structure in the Brazilian Cerrado: a vegetation gradient of aboveground biomass, root mass and consumption by fire, J. Trop. Ecol., 14, 263-283, 1998.

Ellicott, E., Vermote, E., Giglio, L., and Roberts, G.: Estimating biomass consumed from fire using MODIS FRE, Geophys. Res. Lett., 36, L13401, doi:10.1029/2009GL038581, 2009.

Freeborn, P. H., Wooster, M. J., Roberts, G., Malamud, B. D., and $\mathrm{Xu}, \mathrm{W}$.: Development of a virtual active fire product for Africa through a synthesis of geostationary and polar orbiting satellite data, Remote Sens. Environ., 113, 1700-1711, 2009.

Freeborn, P. H., Wooster, M. J., and Roberts, G.: Addressing the spatiotemporal sampling design of MODIS to provide estimates of the fire radiative energy emitted from Africa, Remote Sens. Environ., 115, 475-489, 2011.

Freeborn, P. H., Cochrane, M. A., and Wooster, M. J.: A Decade Long, Multi-Scale Map Comparison of Fire Regime Parameters Derived from Three Publically Available Satellite-Based Fire Products: A Case Study in the Central African Republic, Remote Sens., 6, 4061-4089, 2014a.

Freeborn, P. H., Wooster, M. J., Roberts, G., and Xu, W.: Evaluating the SEVIRI Fire Thermal Anomaly Detection Algorithm across the Central African Republic Using the MODIS Active Fire Product, Remote Sens., 6, 1890-1917, 2014b.

Friedl, M. A., McIver, D. K., Hodges, J. C. F., Zhang, X. Y., Muchoney, D., Strahler, A. H., Woodcock, C. E., Gopal, S., Schneider, A., Cooper, A., Baccini, A., Gao, F., and Schaaf, C.: Global land cover mapping from MODIS: algorithms and early results, Remote Sens. Environ., 83, 287-302, 2002. (data available at: http://reverb.echo.nasa.gov)

Giglio, L., Justice, C. O., and Csiszar, I.: Global distribution and seasonality of active fires as observed with the Terra and Aqua Moderate Resolution Imaging Spectroradiometer (MODIS) sensors, J. Geophys. Res., 111, G02016, 
doi:10.1029/2005JG000142, 2006a. (data available at: http:// reverb.echo.nasa.gov)

Giglio, L., van der Werf, G. R., Randerson, J. T., Collatz, G. J., and Kasibhatla, P.: Global estimation of burned area using MODIS active fire observations, Atmos. Chem. Phys., 6, 957974, doi:10.5194/acp-6-957-2006, 2006b.

Giglio, L., Loboda, T., Roy, D. P., Quayle, B., and Justice, C. O.: An active-fire based burned area mapping algorithm for the MODIS sensor, Remote Sens. Environ., 113, 408-420, 2009. (data available at: http://modis-fire.umd.edu)

Giglio, L., Randerson, J. T., and van der Werf, G. R.: Analysis of daily, monthly, and annual burned area using the fourthgeneration global fire emissions database (GFED4), J. Geophys. Res.-Biogeo., 118, 317-328, doi:10.1002/jgrg.20042, 2013.

Govender, N., Trollope, W. S. W., and van Wilgen, B. W.: The effect of fire season, fire frequency, rainfall and management on fire intensity in savanna vegetation in South Africa, J. Appl. Ecol., 43, 748-758, 2006.

Grégoire, J. M., Eva, H. D., Belward, A. S., Palumbo, I., Simonetti, D., and Brink, A.: Effect of land-cover change on Africa's burnt area, Int. J. Wildland Fire, 22, 107-120, 2013.

Gupta, S. R. and Singh, J. S.: The effect of plant species, weather variables and chemical composition of plant material on decomposition in a tropical grassland, Plant Soil, 59, 99-117, 1981.

Hansen, M. C., Potapov, P. V., Moore, R., Hancher, M., Turubanova, S. A., Tyukavina, A., Thau, D., Stehman, S. V., Goetz, S. J., Loveland, T. R., Kommareddy, A., Egorov, A., Chini, L., Justice, C. O., and Townshend, J. R. G.: High-resolution global maps of 21st-century forest cover change, Science, 342, 850-853, 2013.

Heil, A., Kaiser, J. W., van der Werf, G. R., Wooster, M. J., Schultz, M. G., and van der Gon, H. D.: Assessment of the Real-Time Fire Emissions (GFASv0) by MACC, Tech. Memo. 628, ECMWF, Reading, UK, 2010.

Hély, C., Dowty, P. R., Alleaume, K. K., Korontzi, S., Swap, R. J., Shugart, H. H., and Justice, C. O.: Regional fuel load for two climatically contrasting years in southern Africa, J. Geophys. Res., 108, 8475, doi:10.1029/2002JD002341, 2003a.

Hély, C., Alleaume, S., Swap, R. J., Shugart, H. H., and Justice, C. O.: SAFARI-2000 characterization of fuels, fire behavior, combustion completeness, and emissions from experimental burns in infertile grass savannas in western Zambia, J. Arid Environ., 54, 381-394, 2003b.

Hoffa, E. A., Ward, D. E., Hao, W. M., Susott, R. A., and Wakimoto, R. H.: Seasonality of carbon emissions from biomass burning in a Zambian savanna, J. Geophys. Res., 104, 13841-13853, doi:10.1029/1999JD900091, 1999.

Hurst, D. F., Griffith, D. W. T., Carras, J. N., Williams, D. J., and Fraser, P. J.: Measurements of trace gases emitted by Australian savanna fires during the 1990 dry season, J. Atmos. Chem., 18, 33-56, 1994.

Kaiser, J. W., Heil, A., Andreae, M. O., Benedetti, A., Chubarova, N., Jones, L., Morcrette, J.-J., Razinger, M., Schultz, M. G., Suttie, M., and van der Werf, G. R.: Biomass burning emissions estimated with a global fire assimilation system based on observed fire radiative power, Biogeosciences, 9, 527-554, doi:10.5194/bg-9-527-2012, 2012.

Langenfelds, R. L., Francey, R. J., Pak, B. C., Steele, L. P., Lloyd, J., Trudinger, C. M., and Allison, C. E.: Interannual growth rate varations of atmpospheric $\mathrm{CO}_{2}$ and its ${ }^{13} \mathrm{C}, \mathrm{H}_{2}, \mathrm{CH}_{4}$ and $\mathrm{CO}$ between 1992 and 1999 linked to biomass burning, Global Biogeochem. Cy., 16, 1048, doi:10.1029/2001GB001466, 2002.

Langmann, B., Duncan, B., Textor, C., Trentmann, J., and van der Werf, G. R.: Vegetation fire emissions and their impact on air pollution and climate, Atmos. Environ., 43, 107-116, 2009.

Lehmann, C. E. R., Archibald, S. A., Hoffmann, W. A., and Bond, W. J.: Deciphering the distribution of the savanna biome., New Phytol., 191, 197-209, 2011.

Lehmann, C. E. R., Anderson, T. M., Sankaran, M., Higgins, S. I., Archibald, S., Hoffmann, W. A., Hanan, N. P., Williams, R. J., Fensham, R. J., Felfili, J., Hutley, L. B., Ratnam, J., San Jose, J., Montes, R., Franklin, D., Russell-Smith, J., Ryan, C. M., Durigan, G., Hiernaux, P., Haidar, R., Bowman, D. M. J. S., and Bond, W. J.: Savanna vegetation-fire-climate relationships differ among continents, Science, 343, 548-552, 2014.

Le Page, Y., Oom, D., Silva, J. M. N., Jönsson, P., and Pereira, J. M. C.: Seasonality of vegetation fires as modified by human action: observing the deviation from eco-climatic fire regimes, Global Ecol. Biogeogr., 19, 575-588, 2010.

Meyer, C. P., Cook, G. D., Reisen, F., Smith, T. E. L., Tattaris, M., Russell-Smith, J., Maier, S. W., Yates, C. P., and Wooster, M. J.: Direct measurements of the seasonality of emission factors from savanna fires in northern Australia, J. Geophys. Res.Atmos., 117, D20305, doi:10.1029/2012JD017671, 2012.

Miranda, H. S., Rocha e Silva, E. P., and Miranda, A. C.: Comportamento do fogo em queimadas de campo sujo, in: Impactos de Queimadas em Areas de Cerrado e Restinga, edited by: Miranda, H. S., Saito, C. H., and Dias, B. F. S., Universidade de Brasilia, Brasilia, DF, Brazil, 1-10, 1996.

Moncrieff, G. R., Lehmann, C. E. R., Schnitzler, J., Gambiza, J., Hiernaux, P., Ryan, C. M., Shackleton, C. M., Williams, R. J., and Higgins, S. I.: Contrasting architecture of key African and Australian savanna tree taxa drives intercontinental structural divergence, Global Ecol. Biogeogr., 23, 1235-1244, 2014.

Padilla, M., Stehman, S. V., Litago, J., and Chuvieco, E.: Assessing the temporal stability of the accuracy of a time series of burned area products, Remote Sens., 6, 2050-2068, 2014.

Poulter, B., Frank, D., Ciais, P., Myneni, R. B., Andela, N., Bi, J., Broquet, G., Canadell, J. G., Chevallier, F., Liu, Y. Y., Running, S. W., Sitch, S., and van der Werf, G. R.: Contribution of semiarid ecosystems to interannual variability of the global carbon cycle, Nature, 509, 600-603, 2014.

Prasad, V. K., Kant, Y., Gupta, P. K., Sharma, C., Mitra, A. P., and Badarinath, K. V. S.: Biomass and combustion characteristics of secondary mixed deciduous forests in Eastern Ghats of India, Atmos. Environ., 35, 3085-3095, 2001.

Randerson, J. T., Chen, Y., van der Werf, G. R., Rogers, B. M., and Morton, D. C.: Global burned area and biomass burning emissions from small fires, J. Geophys. Res., 117, G04012, doi:10.1029/2012JG002128, 2012.

Roberts, G., Wooster, M. J., Perry, G. L. W., Drake, N., Rebelo, L.-M., and Dipotso, F.: Retrieval of biomass combustion rates and totals from fire radiative power observations: Application to southern Africa using geostationary SEVIRI imagery, J. Geophys. Res., 110, D21111, doi:10.1029/2005JD006018, 2005.

Roberts, G., Wooster, M. J., and Lagoudakis, E.: Annual and diurnal african biomass burning temporal dynamics, Biogeosciences, 6 , 849-866, doi:10.5194/bg-6-849-2009, 2009. 
Roberts, G., Wooster, M. J., Freeborn, P. H., and Xu, W.: Integration of geostationary FRP and polar-orbiter burned area datasets for an enhanced biomass burning inventory, Remote Sens. Environ., 115, 2047-2061, 2011.

Roberts, G. J. and Wooster, M. J.: Fire Detection and Fire Characterization Over Africa Using Meteosat SEVIRI, IEEE T. Geosci. Remote, 46, 1200-1218, 2008.

Rossiter-Rachor, N. A., Setterfield, S. A., Douglas, M. M., Hutley, L. B., and Cook, G. D.: Andropogon gayanus (gamba grass) invasion increases fire-mediated nitrogen losses in the tropical savannas of northern Australia, Ecosystems, 11, 77-88, 2008.

Roy, D. P. and Boschetti, L.: Southern Africa Validation of the MODIS, L3JRC, and GlobCarbon Burned-Area Products, IEEE T. Geosci. Remote, 47, 1032-1044, 2009.

Roy, D. P., Boschetti, L., Justice, C. O., and Ju, J.: The collection 5 MODIS burned area product - Global evaluation by comparison with the MODIS active fire product, Remote Sens. Environ., 112, 3690-3707, 2008.

Running, S. W., Nemani, R. R., Heinsch, F. A., Zhao, M., Reeves, M., and Hashimoto, H.: A Continuous Satellite-Derived Measure of Global Terrestrial Primary Production, Bioscience, 54, 547560, 2004. (data available at: http://reverb.echo.nasa.gov)

Russell-Smith, J., Murphy, B. P., Meyer, C. P., Cook, G. D., Maier, S., Edwards, A. C., Schatz, J., and Brocklehurst, P.: Improving estimates of savanna burning emissions for greenhouse accounting in northern Australia: Limitations, challenges, applications, Int. J. Wildland Fire, 18, 1-18, 2009.

Sankaran, M., Hanan, N. P., Scholes, R. J., Ratnam, J., Augustine, D. J., Cade, B. S., Gignoux, J., Higgins, S. I., Le Roux, X., Ludwig, F., Ardo, J., Banyikwa, F., Bronn, A., Bucini, G., Caylor, K. K., Coughenour, M. B., Diouf, A., Ekaya, W., Feral, C. J., February, E. C., Frost, P. G. H., Hiernaux, P., Hrabar, H., Metzger, K. L., Prins, H. H. T., Ringrose, S., Sea, W., Tews, J., Worden, J., and Zambatis, N.: Determinants of woody cover in African savannas, Nature, 438, 846-849, 2005.

Sankaran, M., Ratnam, J., and Hanan, N.: Woody cover in African savannas: The role of resources, fire and herbivory, Global Ecol. Biogeogr., 17, 236-245, 2008.

Savadogo, P., Zida, D., Sawadogo, L., Tiveau, D., Tigabu, M., and Odén, P. C.: Fuel and fire characteristics in savanna-woodland of West Africa in relation to grazing and dominant grass type, Int. J. Wildland Fire, 16, 531-539, 2007.

Scholes, R. J. and Archer, S. R.: Tree-grass interactions in savannas, Annu. Rev. Ecol. Syst., 28, 517-544, 1997.

Scholes, R. J., Archibald, S., and von Maltitz, G.: Emissions from Fire in Sub-Saharan Africa: the Magnintude of Sources, Their Variability and Uncertainty, Glob. Environ. Res., 15, 53-63, 2011.

Shea, R. W., Shea, B. W., Kauffman, J. B., Ward, D. E., Haskins, C. I., and Scholes, M. C.: Fuel biomass and combustion factors associated with fires in savanna ecosystems of South Africa and Zambia, J. Geophys. Res., 101, 23551-23568, doi:10.1029/95JD02047, 1996.

Staver, A. C., Archibald, S., and Levin, S. A.: The Global Extent and Determinants of Savanna and Forest as Alternative Biome States, Science, 334, 230-232, 2011.

Stott, P.: Combustion in tropical biomass fires: a critical review, Prog. Phys. Geog., 24, 355-377, 2000.
Turquety, S., Hurtmans, D., Hadji-Lazaro, J., Coheur, P.-F., Clerbaux, C., Josset, D., and Tsamalis, C.: Tracking the emission and transport of pollution from wildfires using the IASI CO retrievals: analysis of the summer 2007 Greek fires, Atmos. Chem. Phys., 9, 4897-4913, doi:10.5194/acp-9-4897-2009, 2009.

van der Werf, G. R., Randerson, J. T., Giglio, L., Gobron, N., and Dolman, A. J.: Climate controls on the variability of fires in the tropics and subtropics, Global Biogeochem. Cy., 22, GB3028, doi:10.1029/2007GB003122, 2008.

van der Werf, G. R., Randerson, J. T., Giglio, L., Collatz, G. J., Mu, M., Kasibhatla, P. S., Morton, D. C., DeFries, R. S., Jin, Y., and van Leeuwen, T. T.: Global fire emissions and the contribution of deforestation, savanna, forest, agricultural, and peat fires (1997-2009), Atmos. Chem. Phys., 10, 11707-11735, doi:10.5194/acp-10-11707-2010, 2010. (data available at: http: //globalfiredata.org)

van Leeuwen, T. T., van der Werf, G. R., Hoffmann, A. A., Detmers, R. G., Rücker, G., French, N. H. F., Archibald, S., Carvalho Jr., J. A., Cook, G. D., de Groot, W. J., Hély, C., Kasischke, E. S., Kloster, S., McCarty, J. L., Pettinari, M. L., Savadogo, P., Alvarado, E. C., Boschetti, L., Manuri, S., Meyer, C. P., Siegert, F., Trollope, L. A., and Trollope, W. S. W.: Biomass burning fuel consumption rates: a field measurement database, Biogeosciences, 11, 7305-7329, doi:10.5194/bg-11-7305-2014, 2014.

Vermote, E., Ellicott, E., Dubovik, O., Lapyonok, T., Chin, M., Giglio, L., and Roberts, G. J.: An approach to estimate global biomass burning emissions of organic and black carbon from MODIS fire radiative power, J. Geophys. Res., 114, D18205, doi:10.1029/2008JD011188, 2009.

Ward, D. E., Susott, R. A., Kauffman, J. B., Babbitt, R. E., Cummings, D. L., Dias, B., Holben, B. N., Kaufman, Y. J., Rasmussen, R. A., and Setzer, A. W.: Smoke and fire characteristics for cerrado and deforestation burns in Brazil: BASE-B experiment, J. Geophys. Res., 97, 14601-14619, doi:10.1029/92JD01218, 1992.

Ward, D. E., Hao, W. M., Susott, R. A., Babbitt, R. E., Shea, R. W., Kauffman, J. B., and Justice, C. O.: Effect of fuel composition on combustion efficiency and emission factors for African savanna ecosystems, J. Geophys. Res., 101, 2356923576, doi:10.1029/95JD02595, 1996.

Wigley, B. J., Bond, W. J., and Hoffman, M. T.: Thicket expansion in a South African savanna under divergent land use: Local vs. global drivers?, Glob. Change Biol., 16, 964-976, 2010.

Wooster, M., Roberts, G., Perry, G. L. W., and Kaufman, Y.: Retrieval of biomass combustion rates and totals from fire radiative power observations: FRP derivation and calibration relationships between biomass consumption, J. Geophys. Res., 110, D24311, doi:10.1029/2005JD006318, 2005.

Wooster, M. J., Roberts, G., Freeborn, P. H., Xu, W., Govaerts, Y., Beeby, R., He, J., Lattanzio, A., Fisher, D., and Mullen, R.: LSA SAF Meteosat FRP products - Part 1: Algorithms, product contents, and analysis, Atmos. Chem. Phys., 15, 1321713239, doi:10.5194/acp-15-13217-2015, 2015. (data available at: http://landsaf.meteo.pt) 